\title{
Induction of a Grapevine Germin-Like Protein (VvGLP3) Gene Is Closely Linked to the Site of Erysiphe necator Infection: A Possible Role in Defense?
}

\author{
Dale Godfrey, ${ }^{1}$ Amanda J. Able, ${ }^{2}$ and lan B. Dry ${ }^{1}$ \\ ${ }^{1}$ CSIRO Plant Industry, PO Box 350, Glen Osmond, SA 5064, Australia; ${ }^{2}$ Plant and Food Science, School of Agriculture, \\ Food \& Wine, The University of Adelaide, Waite Campus, PMB1, Glen Osmond, SA 5064, Australia
}

Submitted 14 February 2007. Accepted 4 May 2007.

\begin{abstract}
Germin-like proteins (GLP) have various proposed roles in plant development and defense. Seven novel GLP cDNA clones were isolated from grapevine (Vitis vinifera cv. Chardonnay). Reverse transcriptase-polymerase chain reaction expression analysis revealed that the $V v G L P$ genes exhibit diverse and highly specific patterns of expression in response to a variety of abiotic and biotic treatments, including challenge by Erysiphe necator, Plasmopara viticola, and Botrytis cinerea, suggesting a diversity of roles for each of the GLP family members. Significantly, one of the grapevine GLP genes, $V v G L P 3$, is induced specifically by $E$. necator infection and expression is closely linked to the site of infection. Subcellular localization of VvGLP3 determined by transient expression of a $V v G L P 3: G F P$ fusion construct in onion cells indicated that the recombinant protein was targeted to the cell wall. Recombinant VvGLP3 was successfully expressed in Arabidopsis thaliana and the partially purified recombinant protein was demonstrated to have superoxide dismutase activity. This data has provided an insight into the diverse nature of the GLP family in grapevine and suggests that $V v G L P 3$ may be involved in the defense response against $E$. necator.
\end{abstract}

Additional keywords: epidermal, powdery mildew.

Powdery mildew of grapevines, caused by the Ascomycetous fungus Erysiphe necator (syn. Uncinula necator), is one of the most economically important diseases of grapevines worldwide. The most commonly cultivated species of grapevine, Vitis vinifera, is highly susceptible to E. necator infection. Powdery mildew of grapevine causes extensive economic losses, not only through lost grape production but also due to costs associated with fungicide application. Economic and environmental impacts and the emerging resistance to fungicides (Savocchia et al. 2004) have increased the need to develop new molecular strategies to confer resistance of grapevine to this important fungal pathogen.

Powdery mildew is an obligate biotroph that only invades host epidermal cells. Similar to that observed for the well-stud-

Corresponding author: I. B. Dry; E-mail: ian.dry@csiro.au

Sequence data for $V v G L P 1$ to $V v G L P 17$ are available under accession numbers EF064171, AY298727, DQ673106, EF064172, EF064173, EF064174, and EF064175.

* The $\boldsymbol{e}$-Xtra logo stands for "electronic extra" and indicates that Figure 8 appears in color online. A supplementary table is also published online. ied Blumeria graminis f. sp. hordei on barley (Green et al. 2002), the E. necator infection process on grapevine tissues is characterized by a distinct sequence of differentiation events following a regular time course (Leinhos et al. 1997). Upon germination, a germ tube emerges from the conidium and elongates; however, unlike Blumeria graminis f. sp. hordei conidia, E. necator conidia produce only a single germ tube. The elongated germ tube subsequently differentiates to form a lobed appressorium from which a penetration peg then emerges and attempts to penetrate the host epidermal cell. Papillae also are produced beneath $E$. necator appressoria during attempted $E$. necator penetration in grapevine (Heintz and Blaich 1990). If penetration is successful, a haustorium is produced in the host epidermal cell.

Powdery mildew infection is accompanied by multiple defense responses, including the formation of papillae at sites of attempted penetration, accumulation of pathogenesis-related (PR) proteins, and hypersensitive cell death (HR) of attacked epidermal cells. Barley host defense responses to powdery mildew attack begin prior to direct fungal penetration activity, suggesting the existence of elicitors originating from the germinating conidia (Caldo et al. 2004; Schweizer et al. 2000). Numerous barley defense-related genes are induced in response to pathogen attack. These genes encode for proteins such as $\beta-1,3-$ glucanase, chitinase, specific peroxidases, phenylpropanoid biosynthesis proteins, regulatory proteins, and hydrogen peroxide metabolism-related proteins (Caldo et al. 2004; Collinge et al. 2002). In comparison, studies on defense-related gene induction in grapevine in response to powdery mildew are limited. Jacobs and associates (1999) observed the induction of a chitinase, $V v C h i 3$, a glucanase, $V v G l u b$, and a thaumatin-like protein, $V v T L 2$, in leaves and berries infected with powdery mildew.

Defense-related proteins are thought to be involved in defense via their antifungal or antimicrobial activities, or by their ability to build barriers against pathogen ingress (Collinge et al. 2002). However, the same defense-related transcripts generally accumulate to similar levels in both compatible and incompatible interactions during the early stages of an interaction, but generally are suppressed in the compatible interaction in later stages (Caldo et al. 2004; Gregersen et al. 1997). Interestingly, the barley germin-like protein (GLP) gene, HvGER4 (formerly $H v O x O L P$ and $H v G L P 4)$, is induced specifically within cells containing papillae effective in preventing penetration, compared with uninoculated control cells and haustorium-containing infected cells (Christensen et al. 2004; Gjetting et al. 2004; Wei et al. 1998).

The GLP family is a large and considerably heterogeneous group of proteins, with amino acid identities between the dif- 
ferent family members ranging from as low as 25 to almost $100 \%$ (Bernier and Berna 2001). GLP genes are expressed in various organs and developmental stages in plants and in response to a number of abiotic and biotic stresses (Bernier and Berna 2001). In total, 32 GLP genes have been identified in Arabidopsis (Carter and Thornburg 1999; Carter et al. 1998), approximately $14 G L P$ genes have been described from Hordeum vulgare (Druka et al. 2002; Wu et al. 2000; Zimmermann et al. 2006), and at least eight different GLP genes are expressed in rice (Membré and Bernier 1998).

A number of GLP have been demonstrated to have oxalate oxidase (OXO) (Dumas et al. 1993; Lane et al. 1993; Zhou et al. 1998) or superoxide dismutase (SOD) (Carter and Thornburg 2000; Christensen et al. 2004; Tabuchi et al. 2003; Yamahara et al. 1999) activity resulting in the production of $\mathrm{H}_{2} \mathrm{O}_{2}$. A GLP from barley also functions as an ADP glucose pyrophosphatase/ phosphodiesterase (AGPPase), catalyzing the hydrolytic breakdown of several NDP-monosaccharides (Rodriguez-Lopez et al. 2001). However, enzyme activity and function for the majority of GLP has not yet been determined.

There are two distinct forms of barley GLP induced during Blumeria graminis infection. One form, HvGER1 (formerly $\mathrm{HvOxOa}$ ), exhibits OXO activity and is located exclusively within the cell walls of leaf mesophyll tissue (Zhou et al. 1998). A second form, HvGER4, exhibits SOD activity but not OXO activity, and has been detected exclusively within the epidermis (Christensen et al. 2004; Wei et al. 1998). HvGER4 is induced in leaf epidermal tissue within $3 \mathrm{~h}$ of inoculation with Blumeria graminis, with maxima at 6 and $24 \mathrm{~h}$, followed by a rapid decline. In barley, papillae formed in host epidermal cell walls in response to the formation of the Blumeria graminis primary and appressorial germ tubes 3 to 4 and 10 to $18 \mathrm{~h}$ postinoculation, respectively. Hence, the spatial and temporal expression of $H v G E R 4$ suggests a role for the protein product in papillae formation (Wei et al. 1998). $\mathrm{H}_{2} \mathrm{O}_{2}$ accumulation has been observed in the papillae adjacent to the primary and appressorial germ tubes (Thordal-Christensen et al. 1997). Superoxide $\left(\mathrm{HO}_{2} \cdot \mathrm{O}_{2}^{-}\right)$produced by NADPH oxidase or peroxidases in response to pathogen attack (Bolwell and Wojtaszek 1997) potentially may be dismutated to $\mathrm{H}_{2} \mathrm{O}_{2}$ by HvGER4, accounting for this accumulation. This $\mathrm{H}_{2} \mathrm{O}_{2}$ could be involved in cross-linking cell wall components during papillae formation, function as a messenger to activate other defense genes (either in the same cell, neighboring epidermal cells, or mesophyll cells), or act directly as an antimicrobial compound (Wei et al. 1998).

Transient overexpression of epidermal-specific wheat TaGLP4 (formerly TaGLP2a) and epidermal-specific barley $H v G E R 4$ both enhanced resistance against Blumeria graminis in wheat and barley, respectively (Christensen et al. 2004; Schweizer et al. 1999). Furthermore, transient silencing of HvGER4 and TaGLP4 by RNA interference reduced basal resistance against Blumeria graminis (Christensen et al. 2004). These studies demonstrate that GLP can reduce the susceptibility of cereals to powdery mildew infection and, thus, may provide a novel molecular strategy to reduce the susceptibility of grapevine to this important fungal pathogen. Here, we report on the cloning and characterization of seven members, $V v G L P 1$ to $V v G L P 7$, of the $V$. vinifera GLP gene family. Examination of the developmental and stress-induced expression patterns of each $V v G L P$ gene suggests dissimilar functions within the grapevine plant. Significantly, expression analysis suggests that one of the grapevine $G L P$ genes, $V v G L P 3$, is specifically induced in epidermal cells in response to powdery mildew infection. Furthermore, a proportion of the VvGLP3 protein is targeted to the extracellular space and shown to catalyze superoxide dismutation. Together, this data suggests a po- tential role for $V v G L P 3$ is in the penetration-based defense response against powdery mildew infection.

\section{RESULTS}

The grapevine GLP family is a multigene family.

Two partial-length cDNA clones, VvGLP2 (DQ673106) and VvGLP3 (DQ673107), were amplified initially from total RNA isolated from powdery mildew-infected grapevine ( $V$. vinifera cv. Chardonnay) leaf tissue using degenerate primers designed to the conserved amino acid domains $\mathrm{LQD}(\mathrm{V} / \mathrm{L} / \mathrm{F}) \mathrm{CV}(\mathrm{A} / \mathrm{G})$ and (N/D)PPHT/L/L/V)HPR present in GLP sequences from other species. Using rapid amplification of cDNA ends (RACE) polymerase chain reaction (PCR) amplification techniques and searches of $V$. vinifera expressed sequence tag (EST) databases, seven full-length GLP cDNAs from grapevine were identified. The nomenclature adopted for the naming of grapevine GLP is based on that convention originally published by Carter and associates (1998) for Arabidopsis GLP and widely adopted in other recent publications on GLP from other dicot species (Aubry et al. 2003; Doll et al. 2003; Kim and Triplett 2004; Lou and Baldwin 2005; Park et al. 2004).

The deduced open reading frames (ORFs) for $V v G L P 1$ to $V v G L P 7$ range in length from 207 to 225 amino acid residues (Fig. 1). All seven grapevine GLP contain three conserved domains referred to as 'germin boxes' characteristic of GLP (Bernier and Berna 2001). Boxes B and C of the grapevine GLP contain the highly conserved histidine and glutamate residues that are involved in binding manganese at the active site of the protein (Requena and Bornemann 1999). Grapevine GLP also contain two conserved cysteine residues involved in stabilizing the barley germin structure via a disulfide bond (Woo et al. 2000). Consistent with GLP from other species (Carter et al. 1998), the grapevine GLP contain either a single N-glycosylation site (VvGLP1, VvGLP3, and VvGLP6) or two putative Nglycosylation sites (VvGLP2, VvGLP4, VvGLP5, and VvGLP7). However, only a few studies have actually demonstrated glycosylation of the purified protein (Carter and Thornburg 2000; Kim et al. 2004; Membré et al. 2000; Yamahara et al. 1999). Variants of the arginine-glycine-asparagine tripeptide, thought to be involved in protein-protein interactions (Swart et al. 1994), also are present in all of the grapevine GLP sequences as either KGD (Lys-Gly-Asp) or KGE (Lys-Gly-Glu). Putative N-terminal signal peptides were predicted using PSORT (Nakai and Kanehisa 1992) for VvGLP2, VvGLP3, VvGLP4, VvGLP6, and VvGLP7 (Fig. 1), but were not predicted for either VvGLP1 or VvGLP5.

The amino acid sequence identity shared between all of the grapevine GLP-deduced amino acid sequences ranges from 35 to $88 \%$. VvGLP1, VvGLP3, VvGLP4, VvGLP5, and VvGLP7 share greater identity (67 to 88\%), whereas VvGLP2 and VvGLP6 share less identity with the other GLP (VvGLP2, 38 to $53 \%$; VvGLP6, 35 to $38 \%$ ). When comparing the VvGLP with GLP and germins from other plant species (Fig. 2), the VvGLP grouped within the GLP subfamilies previously proposed by Carter and Thornburg (2000). VvGLP1, VvGLP3, VvGLP4, VvGLP5, and VvGLP7 grouped within GLP subfamily 1 which also contains the epidermal-specific $H$. vulgare protein, HvGER4 (Wei et al. 1998), and Atriplex lentiformis AlGLP (BAA78563), both of which have demonstrated SOD activities (Christensen et al. 2004; Tabuchi et al. 2003; Zimmermann et al. 2006). VvGLP2 clusters within GLP subfamily 2, along with a Rhicadhesin receptor, PsGER1, from Pisum sativa (Swart et al. 1994) and a Nicotiana plumbaginifolia GLP, Nectarin I, with demonstrated Mn-SOD activity (Carter and Thornburg 2000).VvGLP6 was found to be most closely related to a very diverse group of GLP proteins clustered 
in GLP subfamily 3. This group includes an auxin-binding GLP from Prunus persica, PpABP19 (Ohmiya et al. 1998), and a $H$. vulgare GLP, HvGER2, with AGPPase activity (RodriguezLopez et al. 2001; Vallelian-Bindschedler et al. 1998).

\section{$V v G L P$ genes show different expression patterns} during grapevine development.

Expression of the $V v G L P$ gene family first was examined in a range of different grapevine tissues and developmental stages, including roots, leaves, flowers, and berries (Fig. 3). Both $V v G L P 2$ and $V v G L P 6$ were found to be expressed in both leaves and berries (including skin and pulp), with VvGLP6 expression limited to young preveraison berries. VvGLP5 was expressed only in immature berries prior to the ripening phase (termed veraison) when berries soften, accumulate sugar, and, in red grape, change color. Furthermore, VvGLP5 expression appears to be localized to the berry pulp. Of the tissues examined, $V v G L P l$ was detected only in root tissue. Significantly, no expression of $V v G L P 3, V v G L P 4$, or $V v G L P 7$ was observed in any of the grapevine tissues examined (Fig. 3).

\section{$V v G L P$ genes show differential response} to powdery mildew infection.

To study $V v G L P$ gene expression in response to powdery mildew infection, grapevine leaves and berries naturally infected with $E$. necator were sampled at various levels of infection (Fig. 4A). Powdery mildew infection appeared to have little impact on the basal level of expression of $V v G L P 2$, whereas

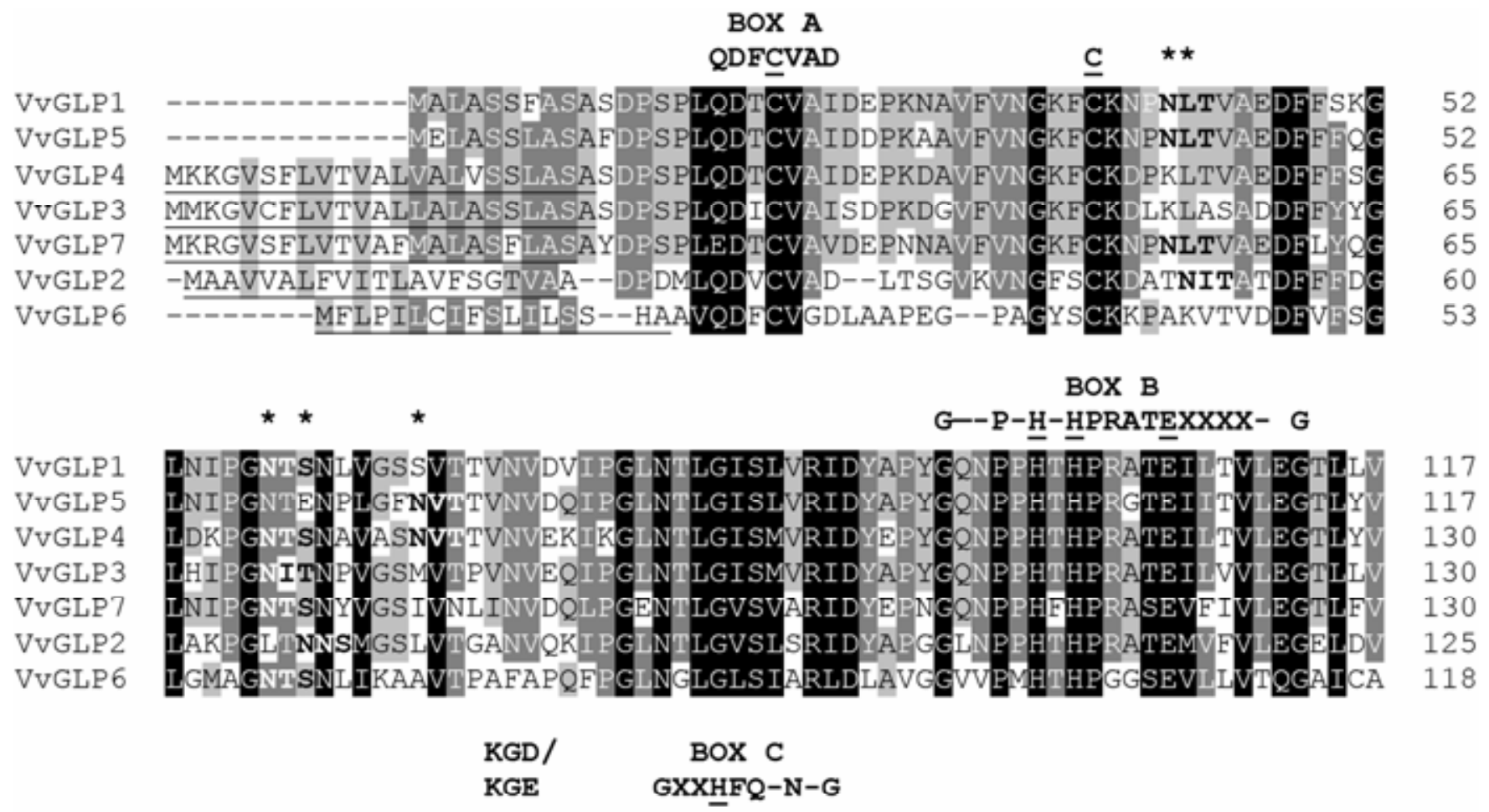

VVGLP1 GFVTSNPQNRIF SKVLNKGDV VFPI GIHFCFNI GHMNAVAAIAGLSSCNPGVINIANAVEGSNP 182

VVGLP5

VVGLP4 GFVT SNPENRL ISKLLNKGDVYVFPI GLIHFQFNVGHANAVAIAALSSONPGVIMIANAVEGSNE GFVTSNTENRL I KKVLNKGDVEVFPI GLIHFQFNVGKTKAVAIAGLSSONPGVIIIANAVEGSDP 195 VVGLP3 GFVTSNNENRLISKVLYKGDVEVFPI GLIHFQFNVGKAKAVAFAGLSS NNPGVIMIANAVEGSDP 195 VVGLP7 GFIT SNPEHRFI SKVLNKGDVEVFPFSLIHFQVNI GHTNAVA IAAFNSCNPGVIMI SSMFGSNP 195 VVGLP2 GFIT--TSNTLISKSIKKGEI FVFPKGLVHFCKNNGEVPAAVISAFNSCLPGTQSIAVSLFAASE 188 VVGLP6 GFISS--ANTVYFKTLKGDIMIFPQGLHFQVNGAGIPSTAFVSFSSPQPGIQILDYALEANDL 181

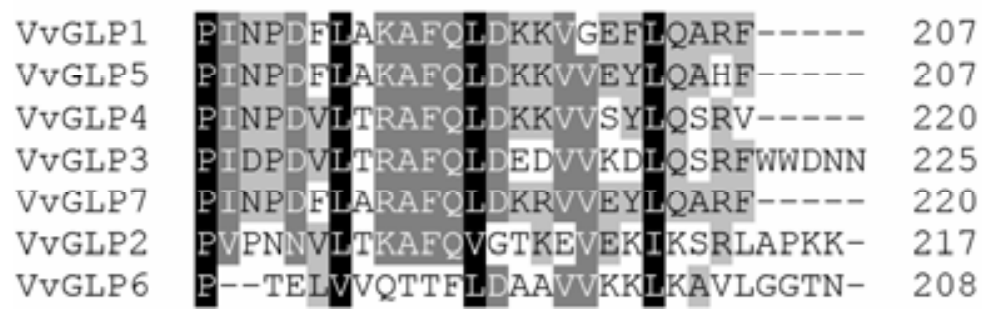

Fig. 1. Deduced amino acid alignment of $V v G L P$ cDNAs. Alignment based on pairwise similarity using the GCG Wisconsin software package program PileUp. Shading represents conservation of amino acid similarity at each position: residues conserved between sequences are shaded in black, dark gray shading indicates similar residues in six out of seven of the sequences, and light gray shading indicates similar residues in four or five out of the seven sequences. Dashes indicate introduced gaps. Putative N-terminal signal sequences are underlined. The conserved germin motifs, boxes A, B, and C, are indicated with the glutamate and the three histidines involved in metal binding and the conserved cysteine residues underlined. Predicted N-glycosylation sites for VvGLP1 (N41 and N58), VvGLP2 (N50 and N68), VvGLP3 (N71), VvGLP4 (N71 and N79), VvGLP5 (N41 and N66), VvGLP6 (N59), and VvGLP7 (N54 and N71) are in bold and indicated with asterisks. Putative arginine-glycine-asparagine-like tripeptides are labeled as KGD/KGE. 
transcript levels of $V v G L P 5$ in infected berries and $V v G L P 6$ in infected leaves decreased dramatically. In terms of those genes not basally expressed in leaves or berries, powdery mildew infection had no effect on $V v G L P 1$ or $V v G L P 7$ transcription. However, significantly, both $V v G L P 3$ and $V v G L P 4$ were induced in leaves and berries infected with E. necator, and the level of induction appeared to be correlated with the area of tissue infected. The accumulation of $V v G L P 3$ transcript, in response to powdery mildew infection, also was verified using artificial inoculation of healthy grapevine leaves and confirmed that $V v G L P 3$ induction coincided with penetration of epidermal cell layer (data not shown).

Owing to the vascular complexity of grapevine leaves, techniques used previously with barley to look at tissue-specific induction of HvGER4 (Gregersen et al. 1997) by separating epidermal and mesophyll tissues could not be used. However, it was possible to separate the skin and pulp tissues of powdery mildew-infected grape berries, which showed that $V v G L P 3$ and $V v G L P 4$ induction occurred specifically within the berry skin tissue (Fig. 4A), suggesting that these genes may be in- duced specifically within infected epidermal cells. To test this further, we examined whether $V v G L P$ gene expression was closely linked to the sites of powdery mildew infection or was induced systemically within the infected leaf. Regions of visible powdery mildew infection (infected regions) were excised and sampled separately from areas on the same leaf which were remote from the obvious infection (remote regions). Accumulation of the powdery mildew-inducible $V v G L P 3$ transcript was found to be restricted to regions of visible infection and was not systemically induced within the infected leaf in regions physically remote from the site of powdery mildew infection (Fig. 4B), supporting the hypothesis that $V v G L P 3$ induction is closely linked to the site of powdery mildew infection.

\section{$V v G L P 3$ is induced specifically in response}

to $E$. necator and not

by other fungal pathogens or wounding.

In order to determine whether the induction of $V v G L P 3$ and $V v G L P 4$ is specific to powdery mildew infection alone or a gen-

\section{GLP subfamily 3}

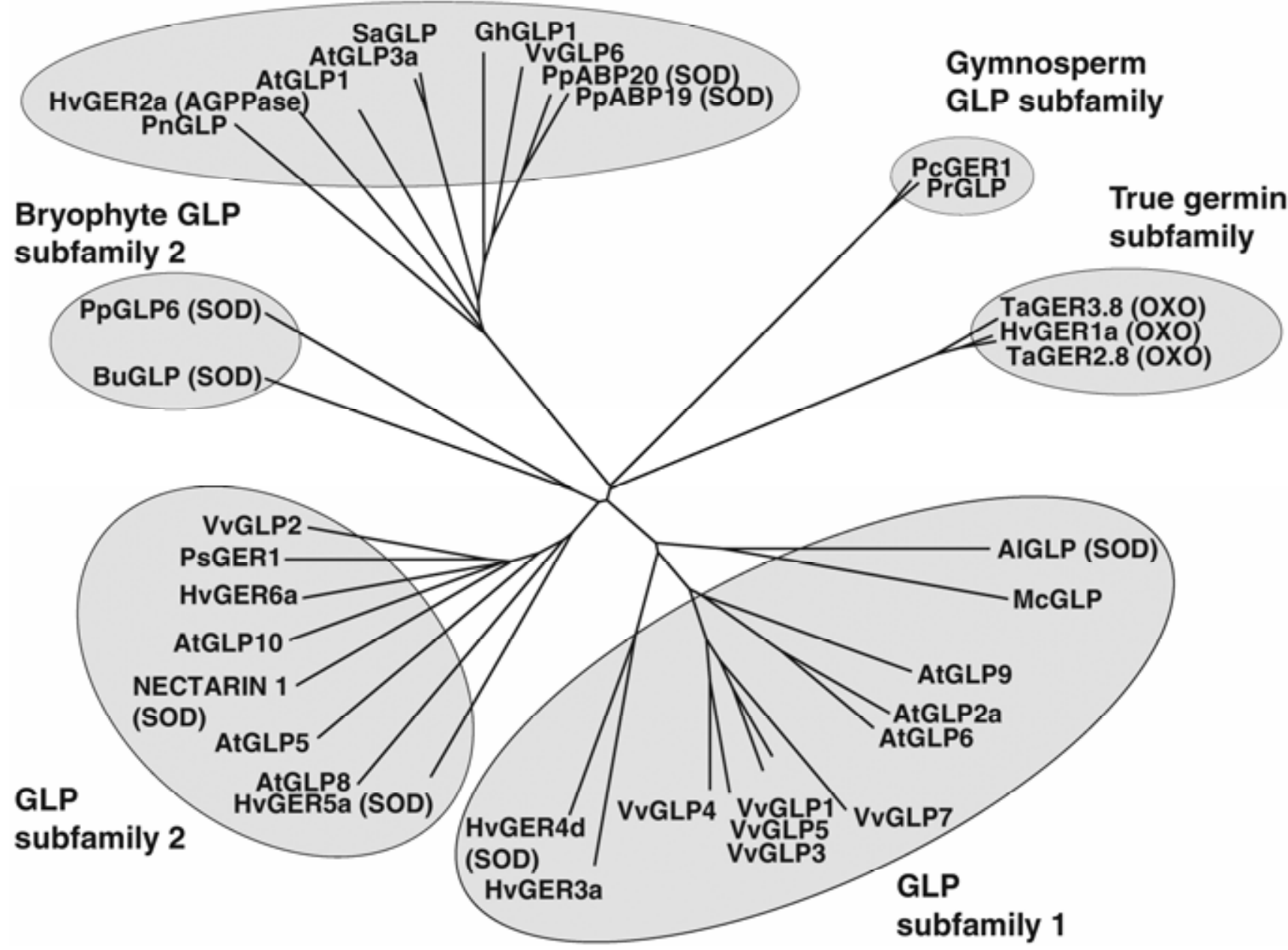

Fig. 2. Unrooted phylogenetic tree of germin-like proteins (GLP). Alignment of deduced amino acid sequences was performed using ClustalX with default parameter settings and displayed with the TreeView program. Branches representing the germin and GLP subfamilies are indicated. Functional activity demonstrated by functional assay is indicated as follows: OXO (oxalate oxidase activity), SOD (superoxide dismutase), and AGPPase (adenosine diphosphate glucose pyrophosphatase activity). The National Center for Biotechnology Information RefSeq/GenBank protein ID of the sequences used for the analysis in this study were AlGLP, BAA78563; AtGLP1, AAB51584; AtGLP2a, AAB51570; AtGLP3a, AAB51566; AtGLP6, AAB51572; AtGLP8, AAB51585; AtGLP9, NP_193199; AtGLP10, NP_191761; BuGLP, BAC53790; GhGLP1, AAF21988; HvGER1a, ABG46232; HvGER2a, ABG46233; HvGER3a, ABG46234; HvGER4d, ABG46236; HvGER5a, ABG46237; HvGER6a, ABG46238; McGLP, AAA33030; Nectarin I, AAF03355; PcGER1, AAC99473; PnGLP, BAA08266; PpABP19, AAD00295; PpABP20, AAB51240; PpGLP6, BAD86502; PrGLP, AAC05146; PsGER1, CAB65369; SaGLP, CAA59257; TaGER2.8, AAA34270; and TaGER3.8, AAA34271. 
eral response to pathogen infection, $V v G L P$ expression was examined in grapevine leaves infected with either the biotrophic Oomycete pathogen Plasmopara viticola (downy mildew) or the necrotrophic fungus Botrytis cinerea. To confirm successful infection by these pathogens, the expression of the grape PR protein gene $V v T l 2$ encoding a thaumatin-like protein (Davies and Robinson 2000) was included in the expression analysis. Significant induction of $V v T l 2$ in response to $P$. viticola infection is clearly shown in Figure 5A and in the leaf tissue surrounding the Botrytis cinerea lesion (Fig. 5B), confirming the successful infection of these tissues by these fungal pathogens.

A low-level induction of $V v G L P 4$ expression was detected in response to $P$. viticola infection (Fig. 5A). However, no $V v G L P 3$ transcript was detected in downy mildew-infected leaves. Similarly, neither $V v G L P 3$ nor $V v G L P 4$ was induced in grape leaves in response to Botrytis cinerea infection (Fig. $5 \mathrm{~B})$. In contrast, both $V v G L P 7$ and $V v G L P 1$ were strongly induced in grape leaves in response to infection by $P$. viticola (Fig. 5A), but only $V v G L P 7$ was induced in leaves in response to infection by Botrytis cinerea (Fig. 5B).

Many PR protein genes are induced in response to both pathogen attack and wounding (Cabello et al. 1994; Krishnaveni et al. 1999; Zemanek et al. 2002), raising the question as to whether the pathogen response is, in fact, a result of the cellular damage which occurs during infection. To determine whether this is also the case for the $V v G L P$ genes, the expression of the pathogen-responsive $V v G L P 3, V v G L P 4, V v G L P 7$, and $V v G L P 1$ genes also was examined in wounded grape leaves (Fig. 5C). The expression of $V v C h i 4 a$, a PR class IV grape chitinase (Robinson et al. 1997), was used as a positive control for the wounding treatment (Fig. 5C). However, unlike $V v C h i 4 A$, the pathogen-inducible $V v G L P$ genes, $V v G L P 3$, $V v G L P 4, V v G L P 7$, and $V v G L P 1$ were not induced in response to wounding. This suggests that the induction of these $V v G L P$ genes during infection is not a generic response to cellular damage but may be related specifically to detection of pathogen ingress. This is further supported by the differential response of $V v G L P 3, V v G L P 4, V v G L P 7$, and $V v G L P 1$ to the different fungal pathogens (Figs. 4A and $5 \mathrm{~A}$ and $\mathrm{B}$ ).

Some changes in expression also were observed for the basally expressed genes $V v G L P 2$ and $V v G L P 6$. $V v G L P 2$ appeared to be upregulated in leaves infected by $P$. viticola and in response to wounding (Fig. 5A and $\mathrm{C}$ ) but was relatively unaffected by Botrytis cinerea infection (Fig. 5B). The expression of $V v G L P 6$, on the other hand, was downregulated in leaf tissue infected with $P$. viticola and Botrytis cinerea (Fig. 5A and $\mathrm{B}$ ), just as it was in powdery mildew-infected tissue (Fig. $4 \mathrm{~A})$. In contrast, there was no clear effect of wounding on $V v G L P 6$ expression.

\section{$V v G L P 3$ induction is not mediated via the salicylic acid} or jasmonate/ethylene signaling pathways.

Salicylic acid (SA)-dependent and jasmonic acid (JA)/ethylene-dependent signaling pathways are known to lead to the activation of defense genes in response to pathogen attack (Glazebrook 2001; Hammond-Kosack and Parker 2003). Hence, the expression of $V v G L P 3$, induced by E. necator (Fig. 4), and $V v G L P 7$, induced by $P$. viticola and Botrytis cinerea (Fig. 5B), was investigated in response to SA, ethephon (ET), and methyl jasmonate (MeJA).

Induction of the grape glutathione-S-transferase $V v G S T 1$ (GenBank accession number AY156048) was used as a positive control for SA treatment of detached leaves while induction of $V v G l u b$, a PR grape $\beta$-1,3-glucanase (Jacobs et al. 1999), was used as a positive control for the ET and MeJA treatments on attached leaves. VvGLP3 was not induced in response to any of the plant hormones tested (Fig. 6A and B).
Like $V v G L P 3, V v G L P 7$ was not induced by SA or JA treatments but was induced in response to ET treatment (Fig. 6A and $\mathrm{B}$ ), suggesting that the ethylene signaling pathway may be involved in the induction of this gene.

\section{VvGLP3 is targeted to the extracellular space in transiently expressing onion cells.}

Given that $V v G L P 3$ induction is closely linked to the site of powdery mildew infection (Fig. 4B), it may have a role in papillae formation, as proposed for the barley powdery mildewinducible HvGER4 (Wei et al. 1998). However, for VvGLP3 to have a role in papillae formation, it would need to be targeted to the extracellular compartment. This premise was investigated by fusing GFP to the C-terminus of $V v G L P 3$ and $V v G L P 2$ ORFs under the control of a $35 \mathrm{~S}$ promoter and transiently expressing these fusion constructs in onion epidermal cells (Fig. 7).

Untargeted free green fluorescent protein (GFP) (35S-GFP) was found to be distributed throughout the cytoplasm and nucleus, whereas distinct patterns of localization were observed for the VvGLP3 and VvGLP2 GFP fusion proteins (Fig. 7A). VvGLP3:GFP was found to be localized to both the cell periphery and the nuclear envelope (Fig. 7A). VvGLP2:GFP was found to be associated with punctate bodies at the cell periph-

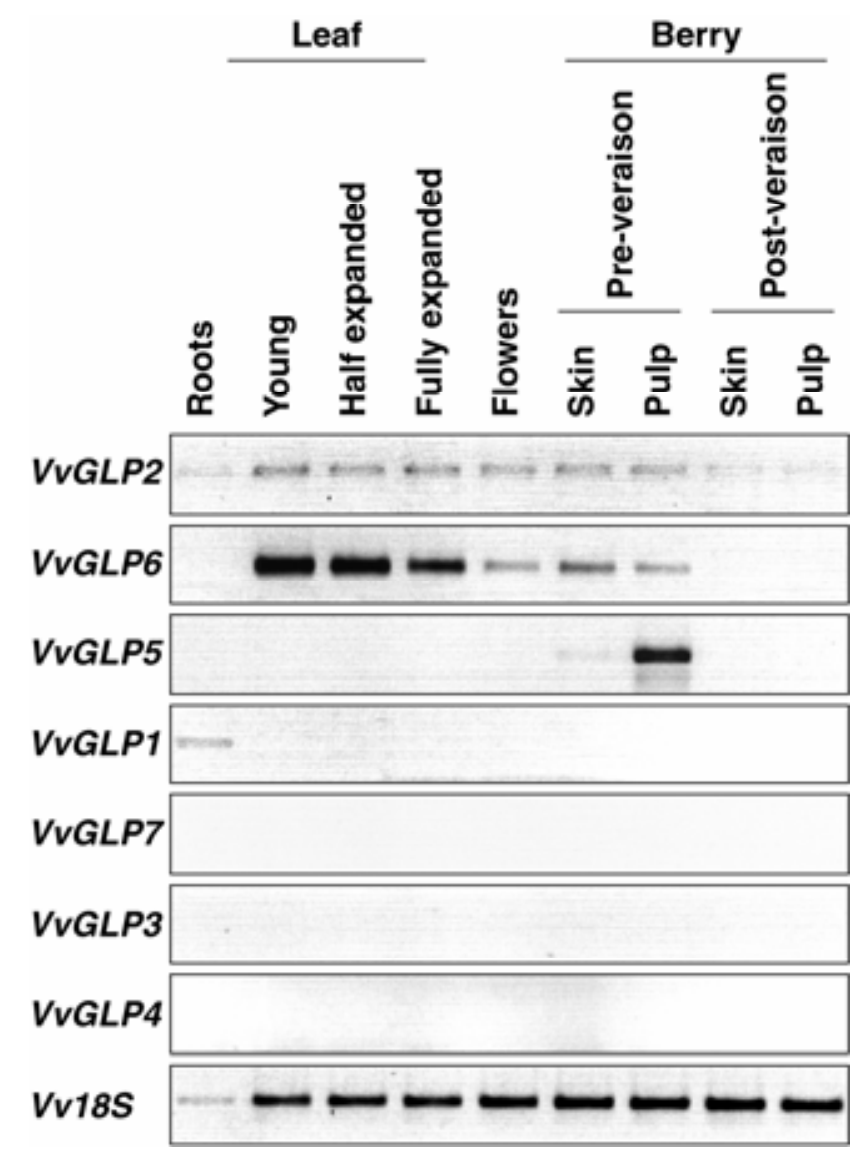

Fig. 3. Basal $V v G L P$ gene expression in grapevine cv. Chardonnay. Transcripts were detected by reverse transcriptase-polymerase chain reaction (RT-PCR) analysis with a gene-specific primer in combination with a $(\mathrm{dT})_{17}$-adaptor primer. Total RNA was extracted from aboveground tissues of vineyard-grown vines and from roots propagated inside a heat-bed. Tissues used were: young leaves (approximately $3 \mathrm{~cm}$ in diameter), halfexpanded leaves (approximately $9 \mathrm{~cm}$ in diameter), fully expanded leaves (approximately $18 \mathrm{~cm}$ in diameter), flowers (50\% capfall), preveraison berries ( 4 weeks postcapfall), and post-veraison berries (12 weeks postcapfall). The concentrations of total RNA used in each RT-PCR reaction were verified by carrying out RT-PCR reactions on each of the samples using $18 \mathrm{~S}$ rRNA primers. 
ery (Fig. 7A) consistent with either a Golgi-localized (Baldwin et al. 2001; Nebenfuhr et al. 1999) or endoplasmic reticulum (ER)-localized protein (Kim et al. 2004). In order to determine whether the VvGLP3:GFP fusion protein at the cell periphery is internal or external to the plasma membrane, onion epidermal cells were plasmolyzed, resulting in shrinkage of the cell protoplasts and retraction of the plasma membranes from the cell walls. Although VvGLP3:GFP was observed to retract with the plasmolyzed plasma membrane, a significant proportion of VvGLP3 remained within the cell wall, suggesting that the VvGLP3 protein is targeted to the extracellular space (Fig. 7B). Unlike VvGLP3:GFP, however, VvGLP2:GFP did not localize to the cell wall in plasmolyzed onion cells (Fig. 7B), suggesting that this protein is not extracellular.

\section{Recombinant VvGLP3 catalyses SOD activity.}

In barley, $\mathrm{H}_{2} \mathrm{O}_{2}$ accumulates at sites of papillae formation in response to Blumeria graminis infection and may be involved in cross-linking reactions during papillae formation (ThordalChristensen et al. 1997). Because the powdery mildew-specific induction and the extracellular localization of VvGLP3 is consistent with a role in papillae formation, an investigation of VvGLP3 enzyme activity was undertaken to determine whether it could catalyze SOD activity, as reported for HvGER4 (Christensen et al. 2004; Zimmermann et al. 2006).

Arabidopsis was transformed with C-terminal His-tagged $V v G L P 3$ and $V v G L P 2$ ORFs, under the control of the Cauliflower mosaic virus (CaMV) $35 \mathrm{~S}$ promoter and the $\mathrm{T}_{2}$ trans- genic lines with the highest levels of transgene expression, as judged by reverse transcriptase (RT)-PCR (Fig. 8A and B), selfed to generate $T_{3}$ seed. This seed was used to inoculate a liquid culture to facilitate the rapid production of a large amount of tissue $(250 \mathrm{mg})$ in a space-efficient manner for assaying the enzyme activity of the recombinant proteins. Denaturation at $65^{\circ} \mathrm{C}$ for $5 \mathrm{~min}$ was chosen to remove heat-unstable proteins on the basis that GLP are extremely heat stable (close to $100 \%$ activity retained after $5 \mathrm{~min}$ at $90^{\circ} \mathrm{C}$ ) (Carter and Thornburg 2000).

Multiple minor proteins with SOD activity are present in wild-type nontransgenic plants (Pan et al. 2001) and also were observed in transgenic Arabidopsis expressing VvGLP3 and $V v G L P 2$. Additional proteins of approximately $100 \mathrm{kDa}$, with strong SOD activity, also were present in the transgenic Arabidopsis plants (Fig. 8C). Crystallography of cereal germin has demonstrated it to have a homohexameric structure, existing as a trimer of dimers, with a molecular mass of approximately $100 \mathrm{kDa}$ (Woo et al. 2000). Germin monomers are stabilized by a disulfide bond between two conserved cysteine residues, which also are present in the grapevine GLP (Fig. 1). Hydrophobic interactions are thought to stabilize the dimers and trimers (Woo et al. 2000). Providing the samples are not boiled, heat-treated GLP migrates on sodium dodecyl sulfate (SDS)-polyacrylamide gels in an oligomeric form (Carter and Thornburg 2000; Christensen et al. 2004). Based on the size of the proteins (approximately $100 \mathrm{KDa}$ ) found exclusively in either extract from the different transgenic Arabidopsis plants,

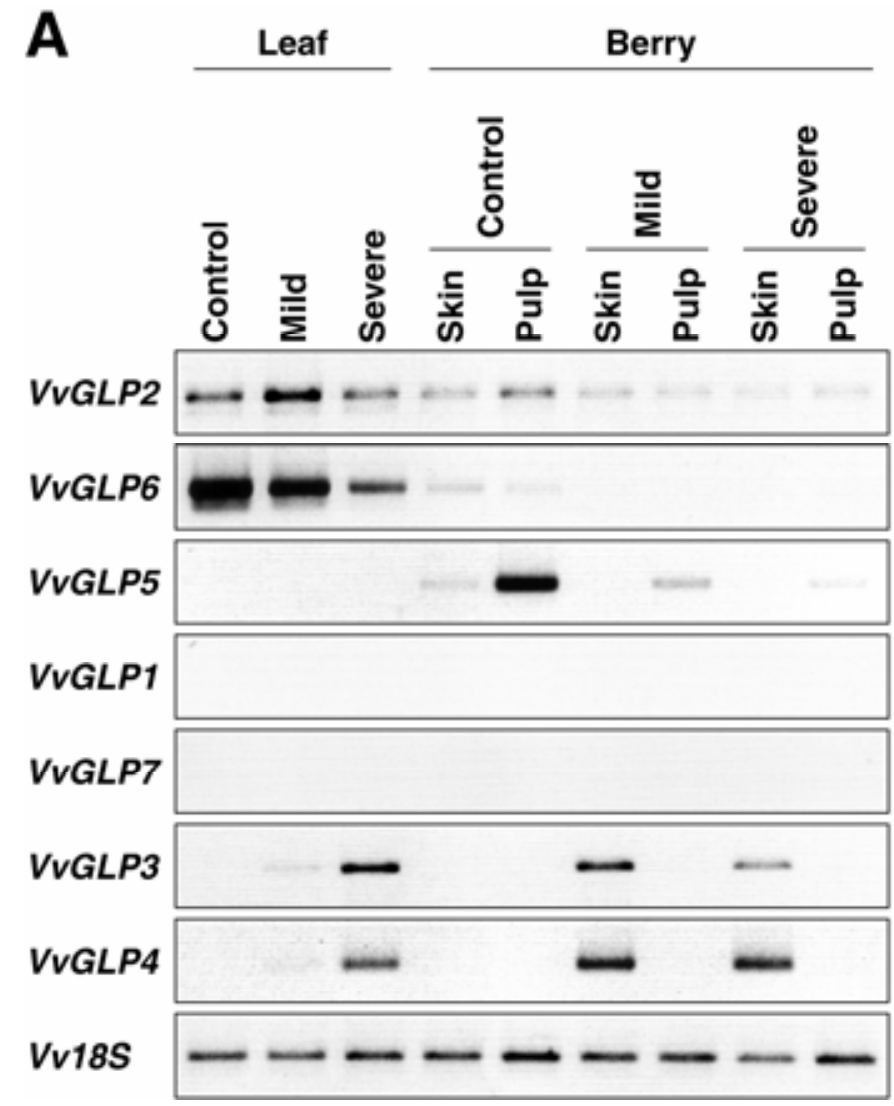

B

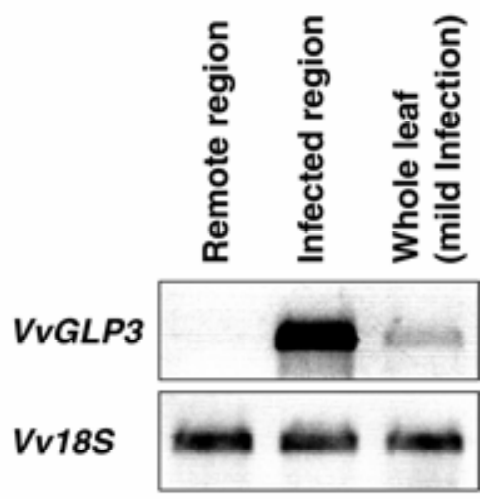

Fig. 4. Erysiphe necator-induced $V v G L P$ gene expression in grapevine. Transcripts were detected by reverse transcriptase-polymerase chain reaction (RTPCR) analysis with a gene-specific primer in combination with a (dT) $)_{17}$-adaptor primer using total RNA. A, Differential response of $V v G L P$ to powdery mildew infection. Leaves (approximately $6 \mathrm{~cm}$ in diameter) and berries ( 8 weeks postcapfall) from vineyard-grown Chardonnay vines were sampled at control (healthy), mild infection ( $<20 \%$ hyphal coverage), and severe infection ( $>20 \%$ hyphal coverage). Berries were separated into skin and pulp components. B, Localization of $V v G L P 3$ expression relative to the site of powdery mildew infection in glasshouse-grown Chardonnay leaves (approximately 6 cm in diameter). Regions of visible powdery mildew infection (infected region), areas on the same leaf remote from the obvious infection (remote region), and whole leaves displaying mild infection ( $<20 \%$ hyphal coverage). The concentrations of total RNA used in each RT-PCR reaction were verified by carrying out RTPCR reactions on each of the samples using $18 \mathrm{~S}$ rRNA primers. 
we may conclude that the proteins demonstrating strong SOD activity are recombinant VvGLP2 and VvGLP3.

Curiously, recombinant VvGLP3 is more electrophoretically mobile than recombinant VvGLP2 under the SDS-polyacrylamide gel electrophoresis (PAGE) conditions applied (Fig. 8C). This difference in mobility cannot be attributed to the difference in size based on putative peptide sequences because the products encoded by recombinant $V v G L P 3$ and $V v G L P 2$ are 225 and 217 amino acids, respectively. Woo and associates (2000) previously have shown that the organization of the hexameric protein structure of GLP can impact their ability to be reduced by SDS and, hence, the apparent disparity of electrophoretic mobility of VvGLP2 and VvGLP3 may be the result of differential resistance to SDS reduction.

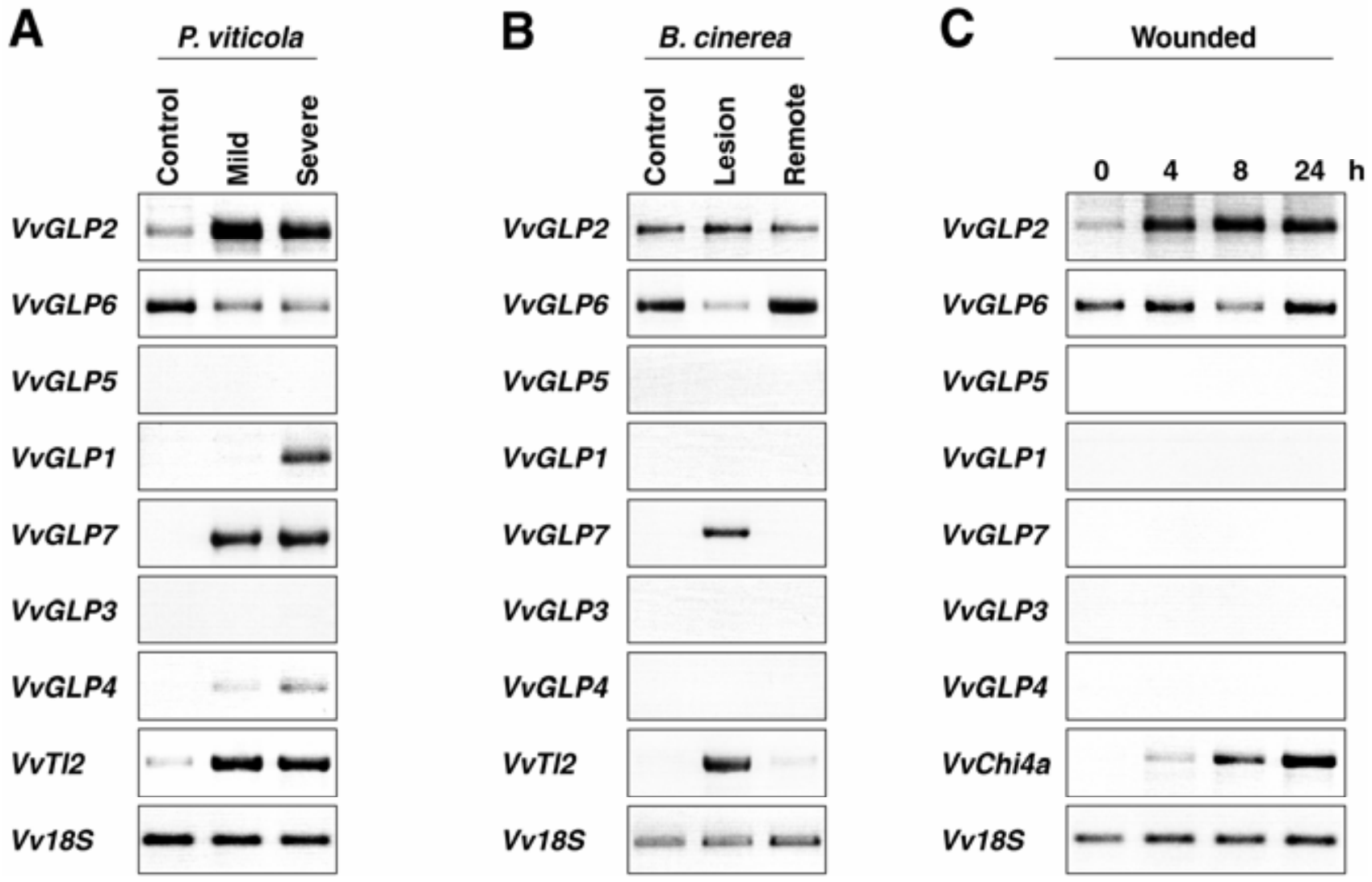

Fig. 5. Expression of $V v G L P$ in response to infection by other fungal pathogens and wounding. Transcripts were detected by reverse transcriptase-polymerase chain reaction (RT-PCR) analysis with a gene-specific primer in combination with a (dT) ${ }_{17}$-adaptor primer using total RNA extracted from glasshouse-grown Chardonnay leaves (approximately $6 \mathrm{~cm}$ in diameter). A, Control leaves (water inoculation only), leaves with mild Plasmopara viticola infection (12 days postinoculation [dpi]), and severe P. viticola infection (20 dpi). B, Control leaves, Botrytis cinerea-infected regions (lesion), and noninfected (remote) regions on the same leaf. C, Leaves sampled at $0,4,8$, and $24 \mathrm{~h}$ postwounding by abrasion with fine sandpaper. The concentrations of total RNA used in each RT-PCR reaction was verified by carrying out RT-PCR reactions on each of the samples using 18S rRNA primers.
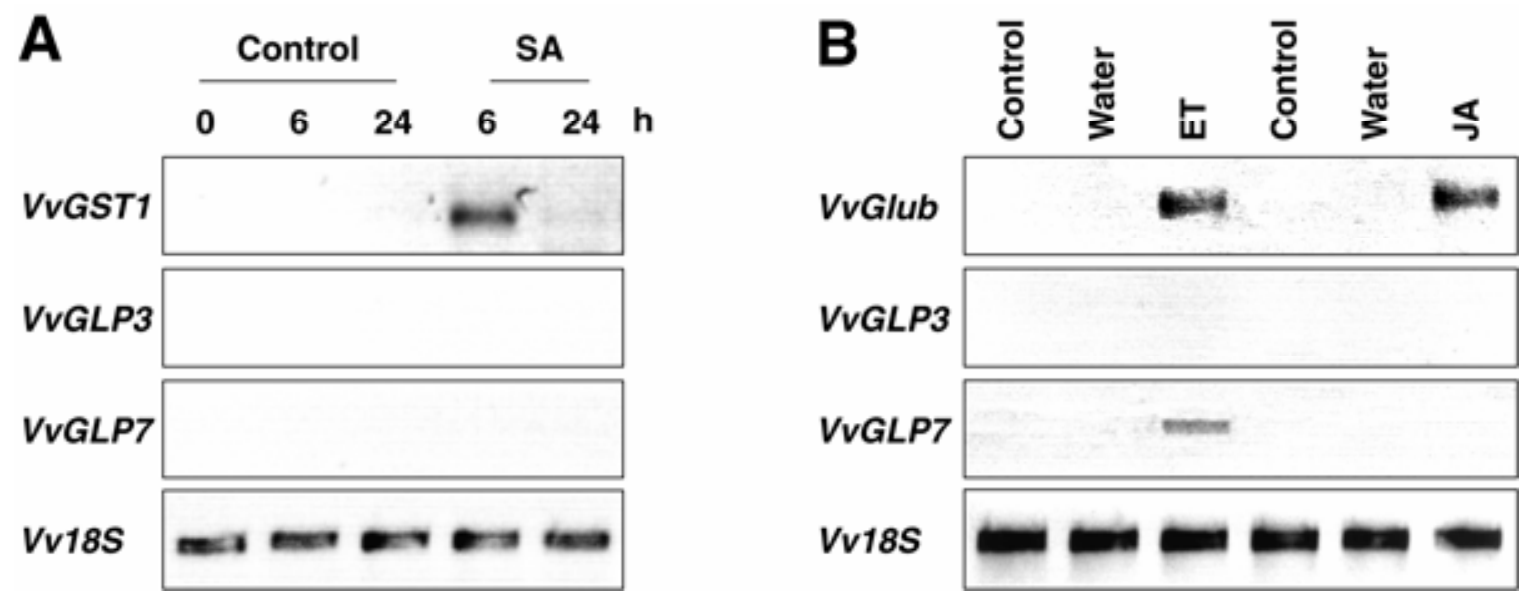

Fig. 6. Expression of pathogen-inducible $V v G L P$ in response to salicylic acid (SA), ethephon (ET), and methyl jasmonate (MeJA). Transcripts were detected by reverse transcriptase-polymerase chain reaction (RT-PCR) analysis with a gene-specific primer in combination with an oligo(dT) adapter primer using total RNA extracted from glasshouse-grown Chardonnay leaves. A, Detached grapevine leaves sampled 6 and $24 \mathrm{~h}$ posttreatment with distilled water or $1 \mathrm{mM}$ SA. B, Leaves sampled from whole vines 2 days posttreatment with distilled ET or MeJA. The concentrations of total RNA used in each RT-PCR reaction were verified by carrying out RT-PCR reactions on each of the samples using $18 \mathrm{~S}$ rRNA primers. 


\section{DISCUSSION}

GLP genes are members of large multigene families exhibiting diverse patterns of expression (Bernier and Berna 2001). Consistent with the GLP families of other species, including Arabidopsis (Carter and Thornburg 1999; Carter et al. 1998), barley (Druka et al. 2002; Wu et al. 2000), and rice (Membré and Bernier 1998), the grapevine genome contains a multigene family of at least seven GLP genes, designated $V v G L P 1$ to $V v G L P 7$ (Fig. 1). The seven grapevine GLP sequences analyzed in this study grouped into three GLP subfamilies (Carter and Thornburg 2000; Nakata et al. 2004), demonstrating that a higher level of conserved amino acid identity exists between subfamily members than between grapevine GLP belonging to different subfamilies (Fig. 2).

Analysis of the basal and inducible expression patterns of each of the grapevine GLP genes (Figs. 3 to 5) suggests that the $V v G L P$ gene family is composed of numerous members with apparently dissimilar functions. A majority of the $V v G L P$ family members analyzed showed basal expression, but with some degree of tissue specificity. For example, $V v G L P 5$ was found to be expressed only in preveraison grape berries (Fig. 3). This level of tissue specificity in grapevine contrasts with GLP expression patterns previously detected in barley, where basal expression of all six barley GLP family members is found in primary leaves, roots, and grain (Zimmermann et al. 2006).

The original impetus for identifying and characterizing grapevine $G L P$ genes arose from observations implicating these genes in the defense response against powdery mildew (Dumas et al. 1995; Wei et al. 1998; Zhang et al. 1995). Powdery mildew infection of grapevine leaves and berries resulted in the induction of two grapevine GLP genes, $V v G L P 3$ and $V v G L P 4$ (Fig. 4A). Neither of these genes was found to be expressed in healthy grapevine tissues (Fig. 3). Furthermore, $V v G L P 3$ was not induced in response to infection by the other important grapevine pathogens, $P$. viticola or Botrytis cinerea (Fig. 5A and B). The expression pattern of $V v G L P 4$ mirrored that of $V v G L P 3$ except that there was some low-level induction in response to $P$. viticola infection.

Using grape berries, we were able to show that $V v G L P 3$ induction occurred specifically within the skin tissue of berries challenged with E. necator (Fig. 4), suggesting that $V v G L P 3$
A

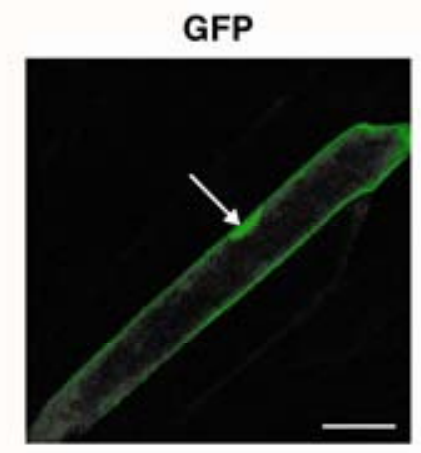

B

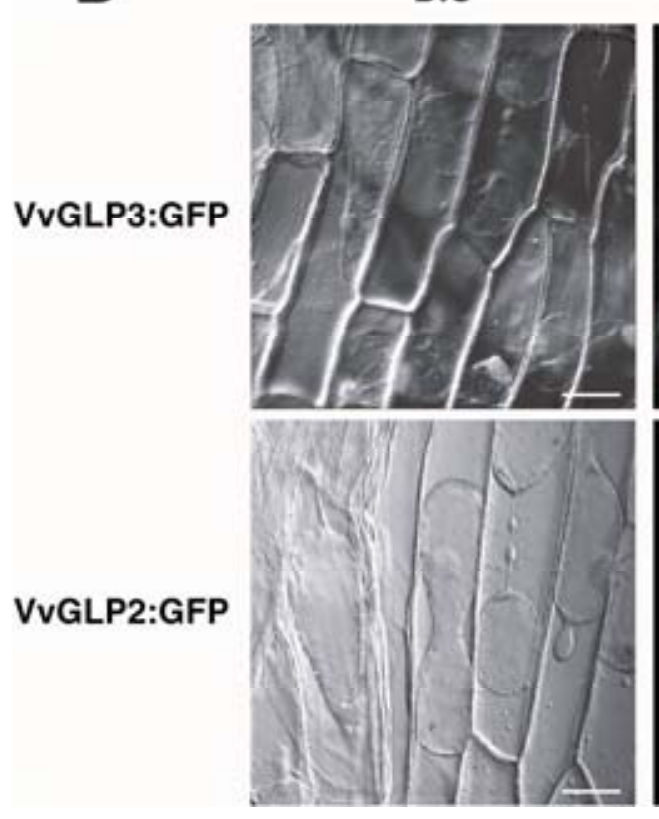

VvGLP3:GFP

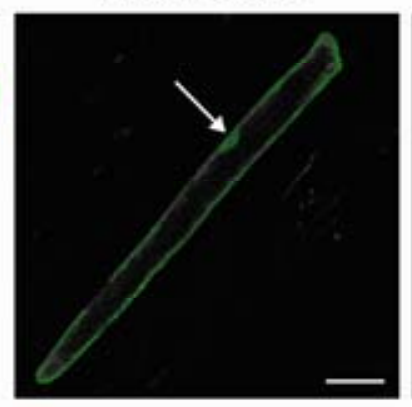

GFP
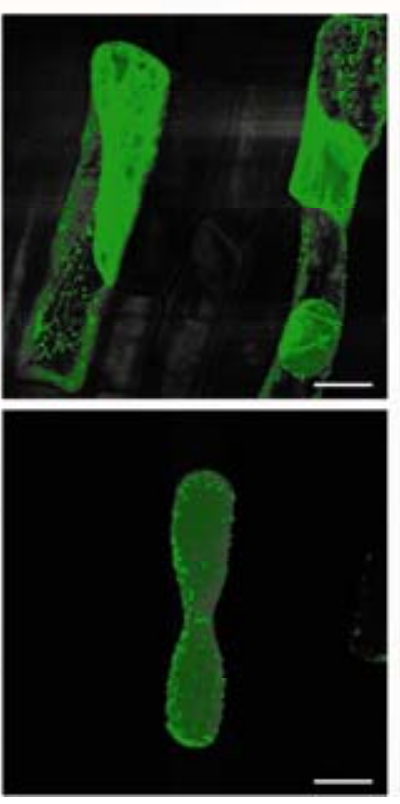

VvGLP2:GFP

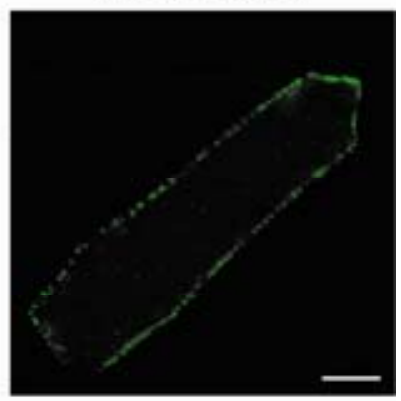

Fig. 7. Targeting of VvGLP:GFP fusion proteins within onion cells. VvGLP-C terminal green fluorescent protein (GFP) fusion constructs were bombarded into onion epidermal cells and cells analyzed for GFP fluorescence using a confocal laser-scanning microscope after 48 h. Full-length $G F P$ open reading frame was used as a control. A, VvGLP3:GFP, VvGLP2:GFP, and free GFP. Nucleus localized protein is indicated by arrow. B, Targeting of VvGLP3:GFP and VvGLP2:GFP within plasmolyzed onion cells. Epidermal peels were incubated in $0.8 \mathrm{M}$ mannitol solution for $1 \mathrm{~h}$ prior to scanning. Differential interference contrast (DIC) images and GFP fluorescence and DIC/GFP merged images are shown from left to right. The patterns shown are typical of those observed in multiple independent bombardment experiments. Arrows indicate cell wall localized protein. Bar $=100 \mu \mathrm{m}$. 
induction, like $H v G E R 4$, may be epidermal specific. However, because the grape berry skin is composed of several cell layers, comprising the epidermis and hypodermis (Ollat et al. 2002), further work will be required to confirm the expression of $V v G L P 3$ specifically within the epidermal layer. Furthermore, $V v G L P 3$ was demonstrated to accumulate specifically in powdery mildew-infected regions, rather than systemically throughout the whole leaf (Fig. 4B), suggesting that $V v G L P 3$ expression is associated only with epidermal cells which have been penetrated by the powdery mildew fungus. In order to obtain supporting evidence for this hypothesis, we have now isolated a 1.8-kb genomic region upstream of $V v G L P 3$ (D. Godfrey and I. B. Dry, unpublished data) for promoter analysis in transgenic Arabidopsis lines inoculated with E. cichoracearum.

Many host genes involved in defense against invading pathogens are known to be activated by SA-dependent or JA/ethylenedependent signaling pathways (Glazebrook 2001; HammondKosack and Parker 2003). VvGLP3 was not found to be induced in response to treatment with SA, ET, or MeJA (Fig. 6), suggesting that these signaling molecules are not involved in powdery mildew-induced $V v G L P 3$ transcription. However, transient induction of $V v G L P 3$ in response to these molecules cannot be excluded. A number of defense-related genes, such as the chitinase gene $V v C h i 4$, also are induced by wounding (Fig. $5 \mathrm{C})$, but there was no sign of induction of $V v G L P 3$ in response to direct wounding of grape leaves (Fig. 5C). This suggests that $V v G L P 3$ induction is not a generic response to cellular damage and raises the question as to the source (i.e., fungal or plant) and type of molecules responsible for $V v G L P 3$ induc- tion. One possibility is that $V v G L P 3$ is induced in response to the release of oligogalacturonides from the epidermal cell wall during E. necator penetration. These biologically active carbohydrates previously have been shown to induce defense responses in a range of plants (Ridley et al. 2001), including grapevine (Aziz et al. 2004), but their effect on GLP expression has not yet been examined.

In addition to $V v G L P 3$ and $V v G L P 4$, both $V v G L P 7$ and $V v G L P 1$ also are induced in response to fungal infection. However, unlike $V v G L P 3$ and $V v G L P 4$, neither $V v G L P 7$ nor $V v G L P 1$ were induced in response to powdery mildew infection but, instead, responded to infection by $P$. viticola (downy mildew) or Botrytis cinerea(Fig. 5). Based on these observations, it is tempting to speculate that these different subgroups of $V v G L P$ genes may be responding to pathogen-specific molecules. However, it is also possible that the differential responses observed may indicate that tissue-specific induction of these genes occurs rather than pathogen-specific induction. For example E. necator (powdery mildew) specifically infects epidermal cells. $P$. viticola (downy mildew), on the other hand, invades grapevine leaves via the stomates and forms haustoria within mesophyll cells (Riemann et al. 2002). If $V v G L P 3$ expression is limited to the epidermal cells, as our data suggests, it may not respond to downy mildew infection of the mesophyll cells. Alternatively, if $V v G L P 7$ and $V v G L P 1$ expression is limited to the mesophyll cells, they would not be expected to respond to E. necator infection of the epidermal cells. Thus, caution should be exercised when interpreting expression data using pathogens which have different infection routes.
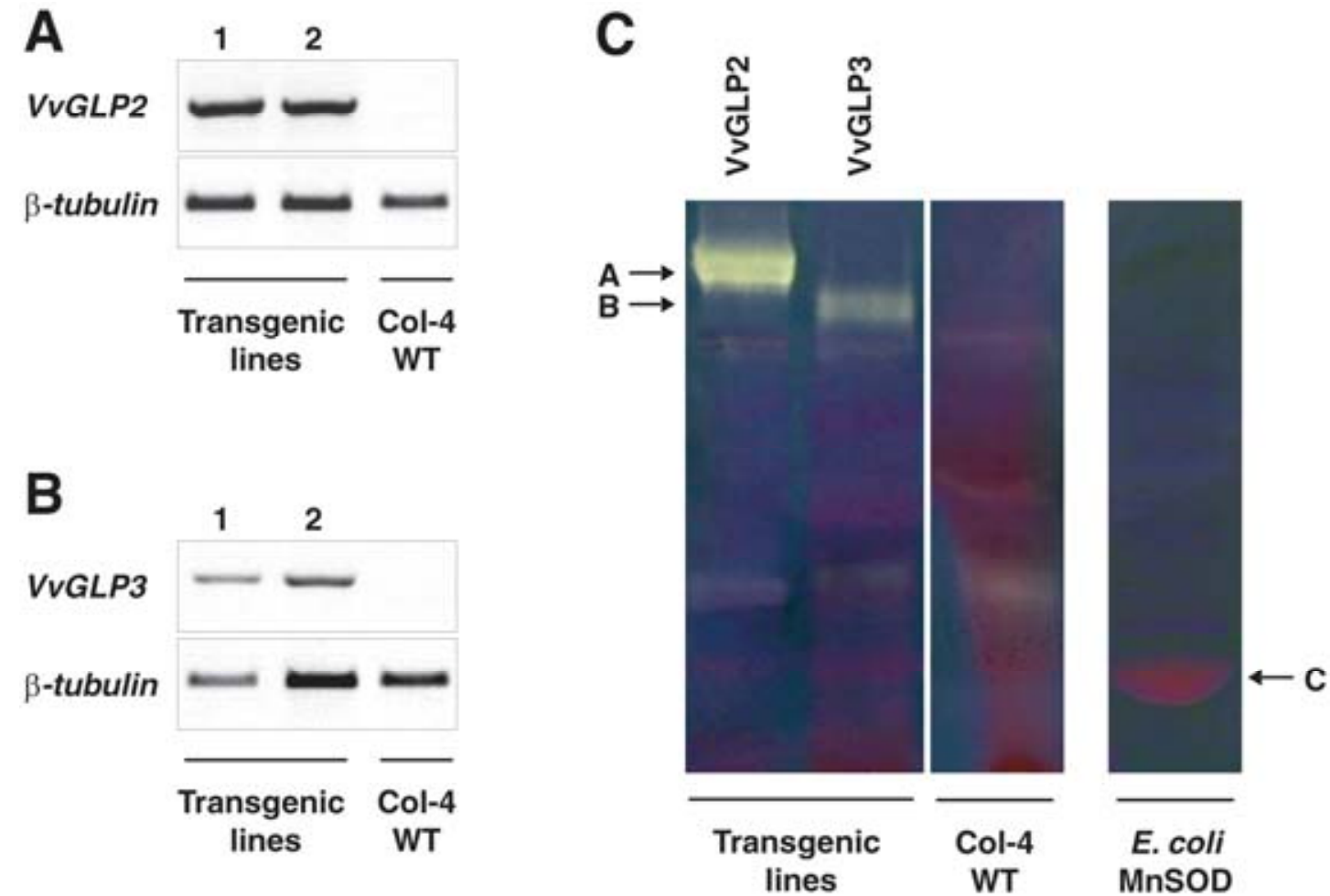

Fig. 8. Identification of VvGLP with superoxide dismutase (SOD) activity. Expression of recombinant $V v G L P$ in $\mathrm{T}_{1}$ transgenic Arabidopsis lines. Total RNA was extracted from leaves of wild-type and $\mathrm{T}_{1}$ transgenic progeny expressing $\mathbf{A}, V v G L P 2$ (lines 1 and 2 ) or $\mathbf{B}, V v G L P 3$ (lines 1 and 2 ) under the control of the Cauliflower mosaic virus $35 \mathrm{~S}$ promoter. Transcripts were detected by reverse transcriptase-polymerase chain reaction (RT-PCR) analysis with gene-specific primers. The concentrations of total RNA used in each RT-PCR reaction was verified by carrying out RT-PCR reactions on each of the samples using $\beta$-tubulin primers. C, In-gel SOD assay detection of recombinant VvGLP expressed in Arabidopsis. Achromatic bands are indicative of SOD activity. Crude extracts were subjected to 4 to $20 \%$ sodium dodecyl sulfate polyacrylamide gel electrophoresis followed by in-gel SOD activity staining. Protein that exhibits SOD activity produces a white band against a blue background. Labels A and B indicate bands of SOD activity observed in extracts from transgenic Arabidopsis lines expressing either $V v G L P 2$ or $V v G L P 3$, respectively, that were not present in extracts from wild-type plants. Label C indicates the position of SOD activity representing Escherichia coli MnSOD (250 U) (Keele et al. 1970) used as a positive control for SOD activity. The size of the proteins was estimated using Precision Plus Protein Standards (BioRad, Regents Park, Australia). 
Such an explanation, however, cannot account for the differential responses of these inducible $V v G L P$ genes to infection by the necrotrophic pathogen Botrytis cinerea, which colonizes all cell layers within the leaf. $V v G L P 7$ alone is induced in response to Botrytis cinerea infection (Fig. 5). Significantly, it also was found to be induced in response to ethylene treatment, whereas $V v G L P 3$ was not (Fig. 6), which is consistent with studies in Arabidopsis indicating that defense against necrotrophic pathogens often is associated with induction of ethylene signaling cascades (Hammond-Kosack and Parker 2003).

In contrast to the pathogen-induced $V v G L P$ genes, $V v G L P 5$ and $V v G L P 6$ are both repressed during powdery mildew infection (Fig. 4A). Pathogen- and stress-induced downregulation of mRNA abundance also has been reported for barley GLP HvGER2 (Vallelian-Bindschedler et al. 1998). HvGER2, an AGPPase with unknown biological function (Rodriguez-Lopez et al. 2001) is also a member of the same GLP subfamily as VvGLP6. Furthermore, Zimmerli and associates (2004) previously has reported repression of a number of genes in Arabidopsis in response to powdery mildew infection. These repressed genes mainly encoded proteins associated with basic metabolism and photosynthesis, leading to the suggestion that there is a diversion of metabolic resources from general metabolism to defense-related metabolism during pathogen attack (Logemann et al. 1995; Zimmerli et al. 2004). This data supports a role for $V v G L P 5$ and $V v G L P 6$ in general metabolism and not in host defense against fungal pathogens.

The highly specific expression pattern of $V v G L P 3$ is similar to that observed for powdery mildew-inducible, epidermalspecific barley GLP, HvGER4, which has been proposed to have a role in papillae formation in response to the formation of primary and appressorial germ tubes by barley powdery mildew (Wei et al. 1998). Schweizer and associates (1999) also demonstrated that overexpression of the epidermal-specific wheat GLP gene, TaGLP2a, only reduced penetration efficiency of Blumeria graminis if the protein was secreted to the extracellular space. VvGLP3 may have a similar role, with a significant proportion of the VvGLP3:GFP fusion protein localized in the extracellular space (Fig. 7B). Interestingly, although no nuclear localization signals are predicted from the translated sequence, some VvGLP3:GFP fusion protein was found to be associated with the nuclear envelope in this transient assay (Fig. 7B). This may have arisen from overexpression, resulting in spill-over of protein to other cellular compartments (Brandizzi et al. 2003). Because the nuclear envelope and the ER are continuous, saturation of secretion to the extracellular space may have led to buildup of VvGLP3 in the nuclear envelope.

Wei and associates (1998) originally postulated that the powdery mildew-inducible epidermal-specific barley $H \mathrm{v} G E R 4$ may be involved in the generation of $\mathrm{H}_{2} \mathrm{O}_{2}$ required for crosslinking reactions during papillae formation, and it was demonstrated subsequently that the recombinant HvGER4 protein expressed in Arabidopsis possessed SOD activity (Christensen et al. 2004; Zimmermann et al. 2006). We have used a similar approach to express recombinant VvGLP3 in Arabidopsis and successfully demonstrated that the recombinant grape protein also is capable of catalyzing SOD activity (Fig. 8C). However, there is still some conjecture as to the importance of this SOD activity in the action of these epidermal-specific GLP proteins in powdery mildew resistance. Although Christensen and associates (2004) were able to show that transient silencing of HvGER4 reduced basal resistance to Blumeria graminis in barley, they were unable to demonstrate a link between $\mathrm{H}_{2} \mathrm{O}_{2}$ levels and loss of HvGER4 protein in these RNAi lines. This led them to speculate that HvGER4 may have an alternate role as a structural protein contributing to cell wall reinforcement during attempted fungal penetration.
In conclusion, we have demonstrated that grapevine contains a $G L P$ gene, $V v G L P 3$, which is induced specifically in response to powdery mildew infection, is targeted to the cell wall of penetrated epidermal cells, and is capable of providing a source of $\mathrm{H}_{2} \mathrm{O}_{2}$ to support cell wall reinforcement in response to attempted penetration. However, it is also clear that this response is not sufficient to stop infection of this grapevine species by E. necator. How does one resolve these two observations? It is well known that the speed and degree of host cell response determines the efficiency of defense against attempted penetration. Our data indicates that, as for barley, a small percentage (10 to $20 \%$ ) of attempted penetrations of grapevine epidermal cells by E. necator are unsuccessful (Godfrey 2006), but that the remaining successful penetrations lead to successful colonization by this pathogen. It is possible that the induction and synthesis of VvGLP3 protein in selected epidermal cells can halt powdery mildew penetration in those cells but that this response is either too slow or absent in other susceptible cells. This hypothesis is supported by the observations of Gjetting and associates (2004), who showed that the accumulation of HvGER4 transcript was significantly greater in barley cells containing effective papillae than in cells which had been successfully penetrated by powdery mildew. Thus, the future challenge for us is to determine what factors regulate the differential VvGLP3 response of individual epidermal cells to attempted powdery mildew penetration, with the aim of genetically enhancing this response in all epidermal cells to generate powdery mildew-resistant grapevines.

\section{MATERIALS AND METHODS}

\section{Plants and pathogens.}

Grapevines were grown in both vineyards and temperaturecontrolled glasshouses, maintained between 23 and $25^{\circ} \mathrm{C}$, at the Waite Campus (Adelaide, South Australia). Arabidopsis thaliana ecotype Columbia-4 plants were grown at $22^{\circ} \mathrm{C}$ under constant light in controlled-temperature growth rooms. E. necator (isolate APC1, provided by E. Scott, University of Adelaide) was maintained on a detached leaf in vitro system as previously described (Donald et al. 2002). Field isolates of $P$. viticola (provided by L. Bartlett, Horticulture Department, South Australia Research and Development Institute, South Australia) were maintained on glasshouse-grown attached grapevine leaves on a 10-day rotation. Infected leaves were incubated upside down on moist filter paper in large petri dishes overnight at $22^{\circ} \mathrm{C}$ under a cycle of $12 \mathrm{~h}$ of light and $12 \mathrm{~h}$ of darkness. The following day, leaves exhibiting sporulating lesions were agitated in water to displace conidia. Diluted spore solution $\left(1 \times 10^{6}\right.$ spores $\left.\mathrm{ml}^{-1}\right)$ was used to inoculate the abaxial leaf surface of attached leaves of glasshouse-grown vines. Leaves were enclosed in plastic bags overnight to maintain humidity. Infected leaves were used to maintain the pathogen and for inoculation studies. Field isolates of Botrytis cinerea (provided by M. Cole, Department of Management, Monash University, Victoria, Australia) were cultured on $3.9 \%(\mathrm{wt} / \mathrm{vol})$ potato dextrose agar (PDA) and incubated in the dark at $25^{\circ} \mathrm{C}$ for 5 days. To obtain a source of active mycelium, infected PDA was cut into $0.5-\mathrm{cm}^{2}$ plugs and excess PDA removed. Infected PDA was used to maintain the isolate and for inoculation studies.

\section{Plant sampling and treatments.}

For grapevine $V v G L P$ expression studies, roots were harvested from 20 cuttings propagated inside a $25^{\circ} \mathrm{C}$ heat-bed in a $2{ }^{\circ} \mathrm{C}$ cold-room. Leaves were collected at different developmental stages from at least 10 different vines. Three flowers were sampled randomly from each of 20 clusters at $50 \%$ capfall, defined as the time when approximately $50 \%$ of the oper- 
cula had fallen from the flowers in a single cluster. Three berries were sampled randomly from each of 20 bunches pre- and postveraison (the onset of grape ripening). Veraison was defined as the stage at which there was a rapid increase in total soluble solids ( ${ }^{\circ}$ Brix) as measured using a hand-held refractometer (refractometer model 10430; Reichert, Vienna). Berries were physically separated into skin and pulp samples using sterile scalpels and tweezers.

For E. necator-inoculated leaves, regions of visible powdery mildew infection (infected region) were excised and sampled separately from areas on the same leaf which were remote from the obvious infection (remote region) and from whole leaves displaying mild infection $(<20 \%$ hyphal coverage). For $P$. viticola infections, triplicate samples of control and infected grapevine leaves were sampled. Botrytis cinerea infections were generated on grapevine leaves by placing an agar plug containing active mycelium in direct contact with the leaf surface. The inoculated leaves then were enclosed in plastic bags containing a small amount of water and the Botrytis cinerea allowed to infect and develop lesions. After 3 days, the regions immediately surrounding the developing lesion (an approximately 2-mm ring) were excised and sampled separately from tissue, remote to but on the same leaf as the lesion. The adaxial surface of grapevine leaves was wounded by gently rubbing with fine sandpaper. Four replicate control and wounded leaves were sampled at $0,4,8$, and $24 \mathrm{~h}$ postwounding. Duplicate grapevine leaves were excised and the petioles submerged in distilled water containing $1 \mathrm{mM} \mathrm{SA}$. Leaves were incubated at $22^{\circ} \mathrm{C}$ under a cycle of $16 \mathrm{~h}$ of light and $8 \mathrm{~h}$ of darkness. Duplicate control leaves were treated in the same way as the individual chemical treatments, but without the addition of SA. Leaves were sampled after 6 and 24 h posttreatment. Ethylene (released from ET) and MeJA treatments were carried out on grapevines in sealed 20-liter clear containers. Vines were either sprayed to runoff with $10 \mathrm{mM}$ ET ([2-chloroethyl] phosphoric acid, Ethrel; Bayer CropScience, East Hawthorn, Australia) or exposed to a cotton ball onto which $400 \mu \mathrm{l}$ of $0.5 \%$ ( $\mathrm{vol} / \mathrm{vol})$ MeJA had been pipetted. Control vines were treated in the same way as the individual chemical treatments but without the addition of MeJA or ET. Four replicate leaves were sampled 2 days posttreatment.

\section{RNA isolation.}

Total RNA was isolated from grape tissues as described by Davies and Robinson (1996). Total RNA was extracted from wild-type and transgenic Arabidopsis using the RNeasy plant mini kit (Qiagen, Valencia, CA, U.S.A.). To eliminate genomic contamination, RNA was DNase treated using the RNase-free DNase kit (Qiagen).

\section{Oligonucleotides.}

Oligonucleotides were synthesized by Geneworks (Adelaide, Australia) and the sequences are listed in the Supplementary Table.

\section{Cloning and analysis of full-length $V v G L P$ cDNAs.}

Synthesis of first-strand cDNA from total RNA was performed with a Preamplification System (Invitrogen, Melbourne, Australia) according to the manufacturer's instructions. Partiallength cDNA clones $V v G L P 2$ and $V v G L P 3$ were amplified from total RNA isolated from powdery mildew-infected grapevine cv. Chardonnay leaf tissue using degenerate primers P1 and $\mathrm{P} 2$, designed to the highly conserved amino acid domains $\mathrm{LQD}(\mathrm{V} / \mathrm{L} / \mathrm{F}) \mathrm{CV}(\mathrm{A} / \mathrm{G})$ and $(\mathrm{N} / \mathrm{D}) \mathrm{PPHT} / \mathrm{I} / \mathrm{L} / \mathrm{V}) \mathrm{HPR}$ in published GLP sequences. Full-length $G L P$ gene sequences were obtained using RACE-PCR (Frohman et al. 1988) with cDNA synthesized from powdery mildew-infected grapevine cv. Chardon- nay berry skin. Amplification of $3^{\prime}$ cDNA ends (3' RACE) was carried out with a gene-specific forward primer and a $(\mathrm{dT})_{17^{-}}$ adaptor primer. For the amplification of the $5^{\prime} \mathrm{cDNA}$ ends, a nested 5' RACE strategy was followed using the 5' RACE system protocol (Invitrogen) according to the manufacturer's instructions. The $3^{\prime}$ ends of $V v G L P 2$ and $V v G L P 3$ were amplified using primers $\mathrm{P} 3$ and $\mathrm{P} 4$, respectively. The 5' ends were amplified using 5' RACE with the gene-specific primers P5 and $\mathrm{P} 6(V v G L P 2)$ and $\mathrm{P} 7$ and $\mathrm{P} 8(V v G L P 3)$ designed to the $3^{\prime}$ end sequence. In addition to cloning the $5^{\prime}$ end of $V v G L P 3$, the $5^{\prime}$ end of another clone, later designated $V v G L P 1$, also was amplified using the $V v G L P 35^{\prime}$ RACE primers (P7 and $\mathrm{P} 8$ ). Using sequence obtained from $V v G L P 1$, the primer P9 was used to amplify the $3^{\prime}$ end of $V v G L P 1$. This primer also was found to amplify the $3^{\prime}$ end of an additional clone, designated $V v G L P 4$. The $5^{\prime}$ end of $V v G L P 4$ subsequently was obtained by 5' RACE using the primers P10, P11, and P12 designed to the $3^{\prime}$ end of $V v G L P 4$. Full-length cDNA sequences were assembled in silico. Two further full-length $V v G L P$ cDNA sequences, $V v G L P 5$ and $V v G L P 6$, were identified from blast searches of The Institute for Genomic Research $V$. vinifera EST database. The primer P13, designed to amplify a $3^{\prime}$ end fragment of $V v G L P 5$ in combination with the $(\mathrm{dT})_{17}$-adaptor primer, also amplified the $3^{\prime}$ end of another $V v G L P$, designated $V v G L P 7$, from Botrytis cinerea-infected grapevine cv. Chardonnay leaf tissue. The $5^{\prime}$ end of $V v G L P 7$ subsequently was obtained by $5^{\prime}$ RACE using gene-specific primers, P14 and P15, designed to the $3^{\prime}$ end of $V v G L P 7$. PCR-amplified DNA fragments were cloned and sequenced in both directions and separate clones were sequenced to verify the accuracy of sequencing.

Plasmid DNA was extracted using the QIAprep spin miniprep kit (Qiagen) and prepared for sequencing using the ABI PRISM BigDye terminator cycle sequencing ready reaction kit (PE Applied Biosystems, Norwalk, CT, U.S.A.), both according to the manufacturer's instructions. Sequencing was carried out at the Institute of Medical and Veterinary Science (Adelaide, Australia). Sequences were analyzed using BLAST searches within the databases maintained by the National Center for Biotechnology Information and the GCG WebANGIS Wisconsin software package operated by the Australian National Genomic Information Service. Alignments were displayed by the GenDoc program. To identify putative signal peptides, the deduced amino acid sequences were analyzed using PSORT Prediction software. $\mathrm{N}$-glycosylation sites were predicted using NetNGlyc 1.0 server.

\section{$V v G L P$ expression analysis.}

$V v G L P$ expression analysis was analyzed by semi-quantitative RT-PCR with the Superscript One Step RT-PCR with Platinum Taq system (Invitrogen). Amplification reactions were carried out with a $G L P$ gene-specific forward primer in combination with a (dT) $)_{17}$-adaptor primer to avoid the possibility of amplifying from any contaminating genomic DNA. A 403-bp VvGLP1 fragment was amplified using P16, a 692-bp $V v G L P 2$ fragment using $\mathrm{P} 3$, a 701-bp $V v G L P 3$ fragment using P17, a 269-bp $V v G L P 4$ fragment using P18, a 661-bp VvGLP5 fragment using P19, a 461-bp VvGLP6 fragment using P20, and a 697-bp $V v G L P 7$ fragment using $\mathrm{P} 21$.

RT-PCR reactions contained $80 \mathrm{ng}$ of total RNA and all primer pairs were used under identical conditions: $30 \mathrm{~min}$ at $50^{\circ} \mathrm{C}$ for first-strand cDNA synthesis; followed by 30 cycles of $15 \mathrm{~s}$ at $94^{\circ} \mathrm{C}, 30 \mathrm{~s}$ at $55^{\circ} \mathrm{C}$, and $1 \mathrm{~min}$ at $68^{\circ} \mathrm{C}$; and a final extension of $10 \mathrm{~min}$ at $72^{\circ} \mathrm{C}$. RT-PCR products were visualized on $1 \%(\mathrm{wt} / \mathrm{vol})$ agarose gels stained with ethidium bromide. The negative image is shown for greater clarity. The concentration of total RNA used in each RT-PCR reaction was verified by carrying out RT-PCR reactions on each of the samples using 
18S rRNA primers P22 and P23. In cases where the expression of a particular $V v G L P$ gene was not detected in any of the samples examined, a positive-control RNA sample always was included in the experiment to verify the PCR conditions. The RT-PCR data shown is representative of results obtained over a number of independent experiments.

\section{Overexpression of $V v G L P$ genes in Arabidopsis.}

Constructs for $35 \mathrm{~S}$ promoter-driven constitutive expression of recombinant $V v G L P 3$ and $V v G L P 2$ in transgenic Arabidopsis were generated with an in-frame C-terminal histidine (His)tag. $V v G L P 2$ and $V v G L P 3$ ORFs were amplified from grapevine cv. Chardonnay cDNA. Forward primers included the native start codon and contained a 5'-XhoI site. The reverse primers contained sequence encoding an in-frame C-terminal $6 \times$ His tag followed by an introduced stop codon and a terminal BamHI site. $V v G L P 3$ was amplified using P24 and P25. $V v G L P 2$ was amplified using P26 and P27. PCR fragments were subcloned into pGEM T-easy vector (Promega, Madison, WI, U.S.A.) and were verified by sequencing. Clones were digested with $X h o \mathrm{I} / \mathrm{Bam} \mathrm{HI}$ to release the ORF fragment for ligation into XhoI/BamHI-digested pART7 vector (Gleave 1992). The expression cassette comprising the CaMV 35S promoter, GLP ORF-His fusion, and nopaline synthase terminator sequence was released by NotI digestion from pART7 and ligated into the binary vector pART27 (Gleave 1992). Constructs were electroporated into Agrobacterium tumefaciens EHA105. Transformation of Arabidopsis was performed using a floral dipping method according to Clough and Bent (1998). $\mathrm{T}_{1}$ seed was selected on $1 \%$ agar containing MS salt mixture (Invitrogen), 1\% (wt/vol) sucrose, and kanamycin at $35 \mu \mathrm{g}$ $\mathrm{ml}^{-1}$. The expression of the $V v G L P 3$ and $V v G L P 2$ transgenes in Arabidopsis $\mathrm{T}_{1}$ lines was verified by RT-PCR analysis using P24 and P25, and P26 and P27, respectively. Primers P28 and P29 were used to amplify $\beta$-tubulin as a control as described by Goetz and associates (2006).

\section{Recombinant VvGLP protein analysis.}

Arabidopsis seed collected from wild-type and transgenic $\mathrm{T}_{2}$ lines $\left(\mathrm{T}_{3}\right.$ seed) was surface sterilized in $50 \%$ bleach (active ingredient $3.5 \%$ [wt/vol] sodium hypochlorite) containing $0.1 \%$ (vol/vol) Tween for $10 \mathrm{~min}$ and washed three times in sterile water. Seed was grown in liquid culture as described by Ramonell and associates (2002) under constant light at $22^{\circ} \mathrm{C}$ with constant agitation at $90 \mathrm{rpm}$ for 2 weeks. Seedlings were frozen with liquid nitrogen and ground into a fine powder using a chilled mortar and pestle. Tissue $(250 \mathrm{mg}$ ) was resuspended in $600 \mu \mathrm{l}$ of $150 \mathrm{mM}$ Tris- $\mathrm{HCl}$ (pH 7.2). Following heat denaturation $\left(65^{\circ} \mathrm{C}\right.$ for $\left.5 \mathrm{~min}\right)$, the sample was centrifuged at $10,000 \times g$ for $10 \mathrm{~min}$. The supernatant was concentrated to less than $10 \mu \mathrm{l}$ using YM-30 Microcon columns (Millipore, North Ryde, Australia) with centrifugation at $10,000 \times g$ for 10 min. Crude extractions were adjusted to10 $\mu \mathrm{l}$ with $150 \mathrm{mM}$ Tris- $\mathrm{HCl}(\mathrm{pH} 7.2)$, mixed with $2 \times$ loading dye $(4 \%$ [wt/vol] SDS, 20\% [vol/vol] glycerol, $0.01 \%$ [wt/vol] bromophenol blue, $125 \mathrm{mM}$ Tris- $\mathrm{HCl}$ [pH 6.8], and 2\% [vol/vol] $\beta$-mercaptoethanol) and loaded onto a 4 to $20 \%$ Tris-glycine-SDS polyacrylamide gel (Life-Gels, Clarkston, GA, U.S.A.). Gels were electrophoresed at approximately $150 \mathrm{~V}$ for $1 \mathrm{~h}$ in SDS running buffer $(0.29 \%$ [wt/vol] Trizma base, $1.44 \%$ [wt/vol] glycine, and $0.1 \%$ [wt/vol] SDS, $\mathrm{pH} 8.3$ ). A modification of the photochemical method of Beauchamp and Fridovich (1971) was used to detect SOD activities on gels. The gel was washed in $50 \mathrm{mM}$ Tris- $\mathrm{HCl}(\mathrm{pH}$ 7.8) for $60 \mathrm{~min}$ to remove SDS, soaked in $0.3 \mathrm{mM}$ nitroblue tetrazolium for $20 \mathrm{~min}$ in the dark, and washed briefly with $36 \mathrm{mM}$ potassium phosphate buffer $(\mathrm{pH}$ 7.8). The gel subsequently was incubated in $36 \mathrm{mM}$ potassium phosphate buffer ( $\mathrm{pH}$ 7.8) containing $28 \mathrm{mM}$ tetramethylenediamine and $2.8 \mu \mathrm{M}$ riboflavin for $15 \mathrm{~min}$ in the dark, and rinsed in $36 \mathrm{mM}$ potassium phosphate buffer ( $\mathrm{pH} 7.8)$. The gel was illuminated on a light box for $15 \mathrm{~min}$ to initiate the photochemical reaction. All procedures were carried out at room temperature.

\section{Analysis of GFP fusion proteins by microprojectile bombardment.}

A variant of the shuttle vector pART7 (Gleave 1992) termed pART7-C'gfp (Selth et al. 2005) was used to produce VvGLP3: GFP and VvGLP2:GFP fusion proteins. The $V v G L P 3$ ORF was amplified using P24 and P30, and the $V v G L P 2$ ORF was amplified using P26 and P31. PCR fragments were subcloned into pGEM T-easy vector and verified by sequencing. After restriction enzyme digestion with $X h o \mathrm{I}$ and $\mathrm{XbaI}$, fragments were ligated into similarly digested pART7-C'gfp to generate C-terminal fusions with GFP. Also used in this experiment was pART7-ATG:GFP, which expresses free GFP (Selth et al. 2005).

Onion (Allium cepa) epidermal strips on 1.2\% (wt/vol) agar were bombarded with each of the vectors as described by Selth and associates (2005). After bombardment, tissue was stored in the dark for $48 \mathrm{~h}$. Epidermal peels were mounted on microscope slides in $1 \times$ phosphate-buffered saline $(137 \mathrm{mM}$ sodium chloride, $2.7 \mathrm{mM}$ potassium chloride, and $10 \mathrm{mM}$ sodium phosphate, $\mathrm{pH}$ 7.4) and GFP was visualized using a Bio-Rad Radiance 2100 confocal laser scanning microscope system with an excitation wavelength of $488 \mathrm{~nm}$. Epidermal cells were plasmolyzed with $0.8 \mathrm{M}$ mannitol for $1 \mathrm{~h}$.

\section{LITERATURE CITED}

Aubry, C., Morere-Le Paven, M. C., Chateigner-Boutin, A. L., TeulatMerah, B., Ricoult, C., Peltier, D., Jalouzot, R., and Limami, A. M. 2003. A gene encoding a germin-like protein, identified by a cDNAAFLP approach, is specifically expressed during germination of Phaseolus vulgaris. Planta 217:466-475.

Aziz, A., Heyraud, A., and Lambert, B. 2004. Oligogalacturonide signal transduction, induction of defense-related responses and protection of grapevine against Botrytis cinerea. Planta 218:767-774.

Baldwin, T. C., Handford, M. G., Yuseff, M.-I., Orellana, A., and Dupree, P. 2001. Identification and characterisation of GONST1, a golgi-localised GDP-mannose transporter in Arabidopsis. Plant Cell 13:2283-2295.

Beauchamp, C., and Fridovich, I. 1971. Superoxide dismutase: Improved assays and an assay applicable to acrylamide gels. Anal. Biochem. 44:276-287.

Bernier, F., and Berna, A. 2001. Germins and germin-like proteins: plant do-all proteins. But what do they do exactly? Plant Physiol. Biochem. 39:545-554.

Bolwell, G. P., and Wojtaszek, P. 1997. Mechanisms for the generation of reactive oxygen species in plant defence-a broad perspective. Physiol. Mol. Plant Pathol. 51:347-366.

Brandizzi, F., Irons, S. L., Johansen, J., Kotzer, A., and Neumann, U. 2003. GFP is the way to glow: Bioimaging of the plant endomembrane system. J. Microsc. 214:138-158.

Cabello, F., Jorrín, J. V., and Tena, M. 1994. Chitinase and beta-1,3-glucanase activities in chickpea (Cicer arietinum). Induction of different isoenzymes in response to wounding and ethephon. Physiol. Plant 92:654660.

Caldo, R. A., Nettleton, D., and Wise, R. P. 2004. Interaction-dependent gene expression in Mla-specified response to barley powdery mildew. Plant Cell 1:2514-2528.

Carter, C., and Thornburg, R. W. 1999. Germin-like proteins: Structure, phylogeny and function. J. Plant Biol. 42:97-108.

Carter, C., and Thornburg, R. W. 2000. Tobacco nectarin I: Purification and characterisation as a germin-like, manganese superoxide dismutase implicated in the defense response of floral reproductive tissues. J. Biol. Chem. 275:36726-36733.

Carter, C., Graham, R. A., and Thornburg, R. W. 1998. Arabidopsis thaliana contains a large family of germin-like proteins: Characterization of cDNA and genomic sequences encoding 12 unique family members. Plant Mol. Biol. 38:929-943. 
Christensen, A. B., Thordal-Christensen, H., Zimmermann, G., Gjetting, T., Lyngkjær, M. F., Dudler, R., and Schweizer, P. 2004. The germinlike protein GLP4 exhibits superoxide dismutase activity and is an important component of quantitative resistance in wheat and barley. Mol. Plant-Microbe Interact. 17:109-117.

Clough, S. J., and Bent, A. F. 1998. Floral dip: A simplified method for Agrobacterium-mediated transformation of Arabidopsis thaliana. Plant J. 16:735-743.

Collinge, D. B., Gregersen, P. L., and Thordal-Christensen, H. 2002. The nature and role of defense response genes in cereals. Pages 146-160 in: The Powdery Mildews: A Comprehensive Treatise. R. R. Belanger, W. R. Bushnell, A. J. Dik, and T. L. W. Carver, eds. The American Phytopathological Society, St. Paul, MN, U.S.A.

Davies, C., and Robinson, S. P. 1996. Sugar accumulation in grape berries: Cloning of two putative vacuolar invertase cDNAs and their expression in grapevine tissues. Plant Physiol. 111:275-283.

Davies, C., and Robinson, S. P. 2000. Differential screening indicates a dramatic change in mRNA profiles during grape berry ripening. Cloning and characterization of cDNAs encoding putative cell wall and stress response proteins. Plant Physiol. 122:803-812.

Doll, J., Hause, B., Demchenko, K., Pawlowski, K., and Krajinski, F. 2003. A member of the germin-like protein family is a highly conserved mycorrhiza-specific induced gene. Plant Cell Physiol. 44:1208-1214.

Donald, T. M., Pellerone, F., Adam-Blondon, A.-F., Bouquet, A., Thomas, M. R., and Dry, I. B. 2002. Identification of resistance gene analogs linked to a powdery mildew resistance locus in grapevine. Theor. Appl Genet. 104:610-618.

Druka, A., Kudrna, D., Dannangara, C. G., von Wettstein, D., and Kleinhofs, A. 2002. Physical and genetic mapping of barley (Hordeum vulgare) germin-like cDNAs. Proc. Natl. Acad. Sci. U.S.A. 99:850-855.

Dumas, B., Sailland, A., Cheviet, J. P., Freyssinet, G., and Pallett, K. 1993. Identification of barley oxalate oxidase as a germin-like protein. C. R. Acad. Sci. Ser. III Sci. Vie 316:793-798.

Dumas, B., Freyssinet, G., and Pallett, K. E. 1995. Tissue-specific expression of germin-like oxalate oxidase during developmental and fungal infection of barley seedlings. Plant Physiol. 107:1091-1096.

Frohman, A., Dush, M. K., and Martin, G. R. 1988. Rapid production of fulllength cDNAs from rare transcripts: Amplification using a single genespecific oligonucleotide primer. Proc. Natl. Acad. Sci. U.S.A. 85:8998 9002

Gjetting, T., Carver, T. L. W., Skøt, L., and Lyngkjær, M. F. 2004. Differential gene expression in individual papilla-resistant and powdery mildewinfected barley epidermal cells. Mol. Plant-Microbe Interact. 17:729-738.

Glazebrook, J. 2001. Genes controlling expression of defence responses in Arabidopsis - 2001 status. Curr. Opin. Plant Biol. 4:301-308.

Gleave, A. P. 1992. A versatile binary vector system with a T-DNA organisational structure conducive to efficient integration of cloned DNA into the plant genome. Plant Mol. Biol. 20:1203-1207.

Godfrey, D. 2006. Characterisation of the germin-like gene family in Vitis vinifera: A possible role in the defence against Erysiphe necator. Ph.D. thesis, University of Adelaide, Adelaide, Australia.

Goetz, M., Vivian-Smith, A., Johnson, S. D., and Koltunow, A. M. 2006. AUXIN RESPONSE FACTOR8 is a negative regulator of fruit initiation in Arabidopsis. Plant Cell 18:1873-1886.

Green, J. R., Carver, T. L. W., and Gurr, S. J. 2002. The formation and function of infection and feeding structures. Pages 66-82 in: The Powdery Mildews: A Comprehensive Treatise. R. R. Belanger, W. R. Bushnell, A. J. Dik, and T. L. W. Carver, eds. The American Phytopathological Society, St. Paul, MN, U.S.A.

Gregersen, P. L., Thordal-Christensen, H., Förster, H., and Collinge, D. B. 1997. Differential gene transcript accumulation in barley leaf epidermis and mesophyll in response to attack by Blumeria graminis f. sp. hordei (syn. Erysiphe graminis f. sp. hordei). Physiol. Mol. Plant Pathol. 51:85-97.

Hammond-Kosack, K. E., and Parker, J. E. 2003. Deciphering plant-pathogen communication: Fresh perspectives for molecular resistance breeding. Curr. Opin. Biotechnol. 14:177-193.

Heintz, C., and Blaich, R. 1990. Ultrastructural and histochemical studies on interactions between Vitis vinifera L. and Uncinula necator (Schw.) Burr. New Phytol. 115:107-117.

Jacobs, A. K., Dry, I. B., and Robinson, S. P. 1999. Induction of different pathogenesis-related cDNAs in grapevine infected with powdery mildew and treated with ethephon. Plant Pathol. 48:325-336.

Keele, B. B., McCord, J. M., and Fridovich, I. 1970. Superoxide dismutase from Escherichia coli B. J. Biol. Chem. 245:6176-6181.

Kim, H. J., and Triplett, B. A. 2004. Cotton fiber germin-like protein. I. Molecular cloningand gene expression. Planta 218:516-524.

Kim, H. J., Pesacreta, T. C., and Triplett, B. A. 2004. Cotton-fiber germinlike protein. II: Immunolocalization, purification, and functional analysis. Planta 218:525-535.
Krishnaveni, S., Muthukrishnan, S., Liang, G. H., Wilde, G., and Manickam, A. 1999. Induction of chitinases and $\beta-1,3$-glucanases in resistant and susceptible cultivars of sorghum in response to insect attack, fungal infection and wounding. Plant Sci. 144:9-16.

Lane, B. G., Dunwell, J. M., Ray, J. A., Schmitt, M. R., and Cuming, A. C. 1993. Germin, a protein marker of early plant development, is an oxalate oxidase. J. Biol. Chem. 268:12239-12242.

Leinhos, G. M. E., Gold, R. E., Duggelin, M., and Guggenheim, R. 1997. Development and morphology of Uncinula necator following treatment with the fungicides kresoxim-methyl and penconazole. Mycol. Res. 101:1033-1046.

Logemann, E., Wu, S.-C., Joachim Schröder, J., Schmelzer, E., Somssich, I. E., and Hahlbrock, K. 1995. Gene activation by UV light, fungal elicitor or fungal infection in Petroselinum crispum is correlated with repression of cell cycle-related genes. Plant J. 8:865-876.

Lou, Y., and Baldwin, I. T. 2005. Silencing of a germin-like gene in Nicotiana attenuata improves performance of native herbivores. Plant Physiol. 140:1126-1136.

Membré, N., and Bernier, F. 1998. The rice genome expresses at least six different genes for oxalate oxidase/germin-like proteins (GenBank AF032971, AF032972, AF032973, AF032974, AF032975, AF032976) (PGR98-021). Plant Physiol. 116:868.

Membré, N., Bernier, F., Staiger, D., and Berna, A. 2000. Arabidopsis thaliana germin-like proteins: Common and specific features point to a variety of functions. Planta 211:345-354.

Nakai, K., and Kanehisa, M. 1992. A knowledge base for predicting protein localization sites in eukaryotic cells. Genomics 14:897-911.

Nakata, M., Watanabe, Y., Sakurai, Y., Hashimoto, Y., Matsuzaki, M., Takahashi, Y., and Satoh, T. 2004. Germin-like protein gene family of a moss, Physcomitrella patens, phylogenetically falls into two characteristic new clades. Plant Mol. Biol. 56:381-395.

Nebenfuhr, A., Gallagher, L. A., Dunahay, T. G., Frohlick, J. A., Mazurkiewicz, A. M., Meehl, J. B., and Staehelin, L. A. 1999. Stopand-go movements of plant Golgi stacks are mediated by the acto-myosin system. Plant Physiol. 121:1127-1141.

Ohmiya, A., Tanaka, Y., Kadowaki, K. I., and Hayashi, T. 1998. Cloning of genes encoding auxin-binding proteins (ABP19/20) from peach: Significant peptide sequence similarity with germin-like proteins. Plant Cell Physiol. 39:492-499.

Ollat, N., Diakou-Verdin, P., Carde, J.-P., Barrieu, F., Gaudillere, J.-P., and Moing, A. 2002. Grape berry development: A review. J. Int. Sci. Vigne Vin 36:109-131.

Pan, S.-M., Chen, M.-K., Chung, M.-H., Lee, K.-W., and Chen, I.-C. 2001. Expression and characterization of monocot rice cytosolic CuZnSOD protein in dicot Arabidopsis. Transgenic Res. 10:343-351.

Park, C.-J., An, J.-M., Shin, Y.-C., Kim, K.-J., Lee, B.-J., and Paek, K.H. 2004. Molecular characterisation of pepper germin-like protein as the novel PR-16 family of pathogenesis-related proteins isolated during the resistance response to viral and bacterial infection. Planta 219:797-806.

Ramonell, K. M., Zhang, B., Ewing, R. M., Chen, Y., Xu, D., Stacey, G., and Somerville, S. 2002. Microarray analysis of chitin elicitation in Arabidopsis thaliana. Mol. Plant Pathol. 3:301-311.

Requena, L., and Bornemann, S. 1999. Barley (Hordeum vulgare) oxalate oxidase is a manganese-containing enzyme. Biochem. J. 343:185-190.

Ridley, B. L., O’Neill, M. A., and Mohnen, D. 2001. Pectins: Structure, biosynthesis, and oligogalacturonide-related signaling. Phytochemistry 57:929-967.

Riemann, M., Buche, C., Kassemeyer, H.-H., and Nick, P. 2002. Cytoskeletal responses during early development of the downy mildew of grapevine (Plasmopara viticola). Protoplasma 219:13-22.

Robinson, S. P., Jacobs, A. K., and Dry, I. B. 1997. A class IV chitinase is highly expressed in grape berries during ripening. Plant Physiol. 114:771-778

Rodriguez-Lopez, M., Baroja-Fernandez, E., Zandueta-Criado, A., MorenoBruna, B., Munoz, F. J., Akazawa, T., and Pozueta-Romero, J. 2001. Two isoforms of a nucleotide-sugar pyrophosphatase/phosphodiesterase from barley leaves (Hordeum vulgare L.) are distinct oligomers of HvGLP1, a germin-like protein. FEBS (Fed. Eur. Biochem. Soc.) Lett. 490:44-48.

Savocchia, S., Stummer, B. E., Wicks, T. J., van Heeswijck, R., and Scott, E. S. 2004. Reduced sensitivity of Uncinula necator to sterol demethylation inhibiting fungicides in southern Australian vineyards. Australas. Plant Pathol. 33:465-473.

Schweizer, P., Christoffel, A., and Dudler, R. 1999. Transient expression of members of the germin-like gene family in epidermal cells of wheat confers disease resistance. Plant J. 20:541-552.

Schweizer, P., Kmecl, A., Carpita, N., and Dudler, R. 2000. A soluble carbohydrate elicitor from Blumeria graminis f. sp. tritici is recognised by a broad range of cereals. Physiol. Mol. Plant Pathol. 56:157-167. 
Selth, L. A., Dogra, S. C., Rasheed, M. S., Healy, H., Randles, J. W., and Rezaian, M. A. 2005. A NAC domain protein interacts with Tomato leaf curl virus replication accessory protein and enhances viral replication. Plant Cell 17:311-325.

Swart, S., Logman, T. J., Smit, G., Lugtenberg, B. J., and Kijne, J. W. 1994. Purification and partial characterization of a glycoprotein from pea (Pisum sativum) with receptor activity for rhicadhesin, an attachment protein of Rhizobiaceae. Plant Mol. Biol. 24:171-183.

Tabuchi, T., Kumon, T., Azuma, T., Nanmori, T., and Yasuda, T. 2003. The expression of a germin-like protein with superoxide dismutase activity in the halophyte Atriplex lentiformis is differentially regulated by wounding and abscisic acid. Physiol. Plant 118:523-531.

Thordal-Christensen, H., Zhang, Z., Wei, Y., and Collinge, D. B. 1997. Subcellular localization of $\mathrm{H}_{2} \mathrm{O}_{2}$ in plants. $\mathrm{H}_{2} \mathrm{O}_{2}$ accumulation in papillae and hypersensitive response during the barley-powdery mildew interaction. Plant J. 11:1187-1194.

Vallelian-Bindschedler, L., Mosinger, E., Metraux, J. P., and Schweizer, P. 1998. Structure, expression and localization of a germin-like protein in barley (Hordeum vulgare L.) that is insolubilized in stressed leaves. Plant Mol. Biol. 37:297-308.

Wei, Y., Zhang, Z., Anderson, C. H., Schmelzer, E., Gregersen, P. L., Collinge, D. B., Smedegaard-Petersen, V., and Thordal-Christensen, H. 1998. An epidermis/papilla-specific oxalate oxidase-like protein in the defence response of barley attacked by the powdery mildew fungus. Plant Mol. Biol. 36:101-112.

Woo, E. J., Dunwell, J. M., Goodenough, P. W., Marvier, A. C., and Pickersgill, R. W. 2000. Germin is a manganese containing homohexamer with oxalate oxidase and superoxide dismutase activities. Nat. Struct. Biol. 7:1036-1040.

Wu, S. P., Druka, A., Horvath, H., Kleinhofs, A., Kannangara, C. G., and von Wettstein, D. 2000. Functional characterization of seed coat-specific members of the barley germin gene family. Plant Physiol. Biochem. 38:685-698.
Yamahara, T., Shiono, T., Suzuki, T., Tanaka, K., Takio, S., Sato, K Yamazaki, S., and Satoh, T. 1999. Isolation of a germin-like protein with manganese superoxide dismutase activity from cells of a moss, Barbula unguiculata. J. Biol. Chem. 274:33274-33278.

Zemanek, A. B., Ko, T.-S., Thimmapuram, J., Hammerschlag, F. A., and Korban, S. S. 2002. Changes in $\beta$-1,3-glucanase mRNA levels in peach in response to treatment with pathogen culture filtrates, wounding, and other elicitors. J. Plant Physiol. 159:877-889.

Zhang, Z., Collinge, D. B., and Thordal-Christensen, H. 1995. Germin-like oxalate oxidase, a $\mathrm{H}_{2} \mathrm{O}_{2}$-producing enzyme, accumulates in barley attacked by the powdery mildew fungus. Plant J. 8:139-145.

Zhou, F., Zhang, Z., Gregersen, P. L., Mikkelsen, J. D., de Neergaard, E., Collinge, D. B., and Thordal-Christensen, H. 1998. Molecular characterization of the oxalate oxidase involved in the response of barley to the powdery mildew fungus. Plant Physiol. 117:33-41.

Zimmerli, L., Stein, M., Lipka, V., Schulze-Lefert, P., and Somerville, S. 2004. Host and non-host pathogens elicit different jasmonate/ethylene responses in Arabidopsis. Plant J. 40:633-646.

Zimmermann, G., Bäumlein, H., Mock, H.-P., and Himmelbach, A. S., P. 2006. The multigene family encoding germin-like proteins of barley. Regulation and function in basal host resistance. Plant Physiol. 142:181-192.

\section{AUTHOR-RECOMMENDED INTERNET RESOURCES}

Australian National Genomic Information Service: www.angis.org.au Center for Biological Sequence Analysis NetNGlyc 1.0 server: www.cbs.dtu.dk

National Center for Biotechnology Information: www.ncbi.nlm.nih.gov/BLAST

National Resource for Biomedical Supercomputing GenDoc program: www.psc.edu/biomed/genedoc

PSORT Prediction software: psort.nibb.ac.jp 